\title{
دراسة تحليلية لإعلانات حملات ضد الإرهاب
}

\section{مروة محمد صالح جاد (•) - (م)}

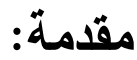

يعد الإرهاب ظاهرة إجرامية منظمة، تهدف إلى خلق جو عام من الخوف والرعب والتهديد في

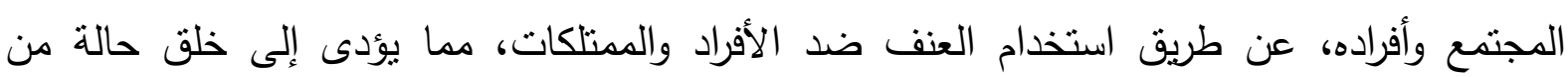
الفوضى العامة، وإلى ضرب الاقتصاديات وزعزعة استقرار الدول.

كما أن ظاهرة الإرهاب قديمة ولكنها انتشرت بشكل غير مسبوق في العقد الأخير من القرن

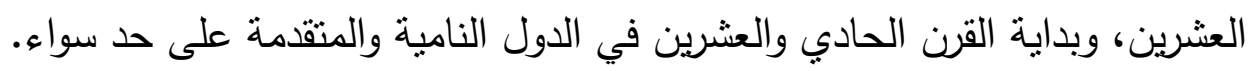

وكان ظهور الإرهاب بسبب الآثار السلبية التي حدثت في حياة الهجتمعات البشرية، ولم يكن الإعلام ببعيد عن ذلك كله، فالإعلام هو لغة العصر يعبر عن العصر يؤثر فيه ويتأثر به. ولقد عرف المرصد العربي للنطرف والإرهاب بأنه: "أي عمل يهدف إلى ترويع فرد، أو جماعة، أو دولة، بغية تحقيق أهداف، لا تجيزها القوانين المحلية، والإقليمية، (الدولية". (http://arabobservatory.com)

فبعد أحداث الحادي عشر من سبتمبر في الولايات المتحدة الأمريكية، فقد ذهبت أغلب التغطيات،

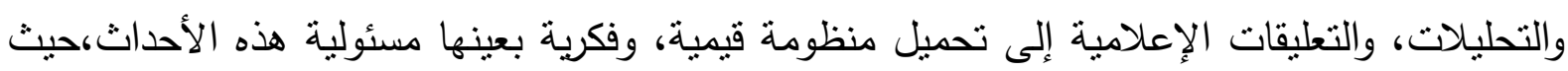
اتهمت الإسلام بقمع الحريات وممارسة العنف والتسلط. ومن هنا يتضح لنا: أن الإعلام يلعب دوراً مهماً ومؤثراً في توجهات الرأي العام واتجاهاته، وصياغة

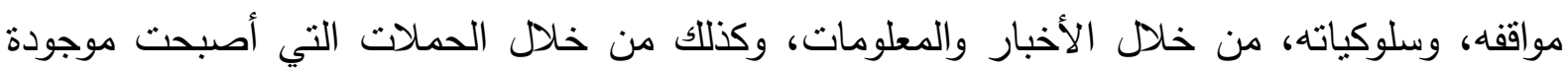

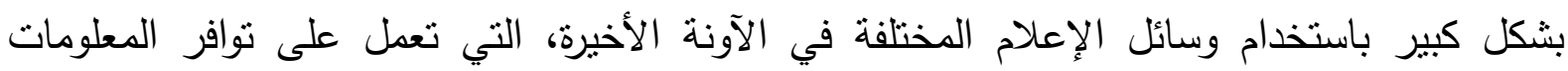

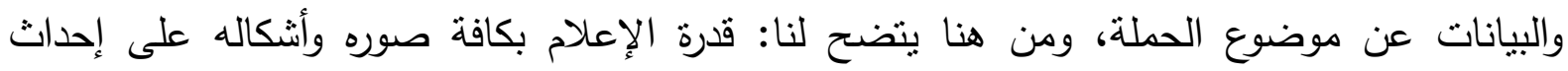
تغييرات في المفاهيم والممارسات (الفردية - المجتمعية)، وذلك من خلال عملية التوعية التي تقوم بهات الاعلات

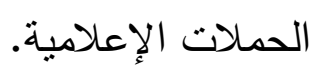

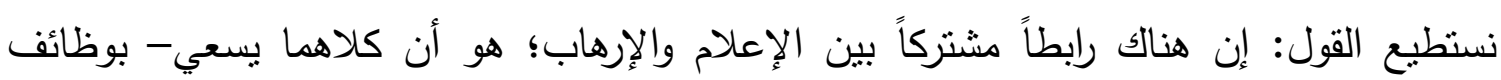

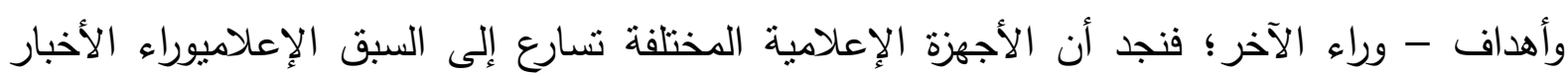

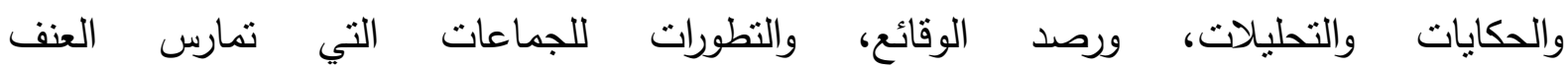


الاجتماعي،والسياسيوالإرهابي، ومن هنا يسعى الإعلام إلى متابعتها، بهدف تغطية وقائع العنف، أما

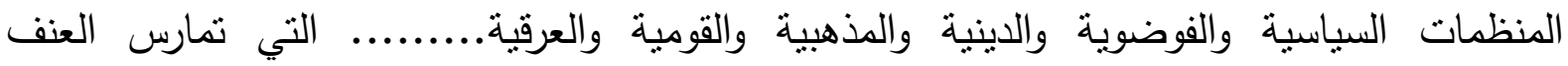
والإرهابفهي تسعى- كذلك- وراء الأجهزة الإعلامية لكى توصل رسائلها السياسية، والنفسية، وتحقق

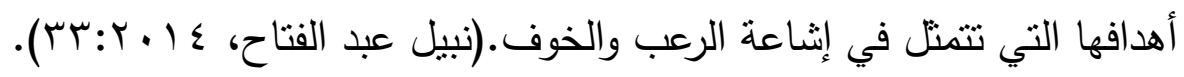

ومن ذلك يتضح لنا: أن حملات التوعية العامة (الحملات الإعلامية) هيظاهرة اجتماعية سليمة،

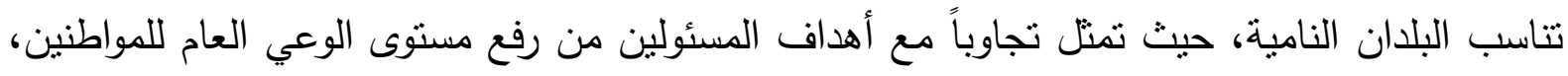
وتدعيم هذه الأهداف بالتوعية.

وتعرف الحملات بأنها: "جهد منظم يهدف إلى إقناع الآخرين بقبول،أو تعديل،أو الابتعاد عن أفكار

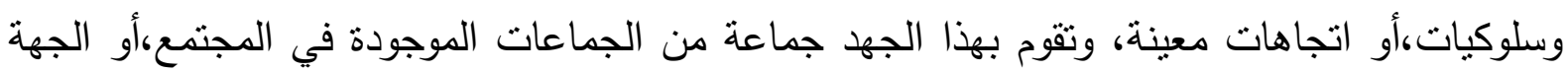

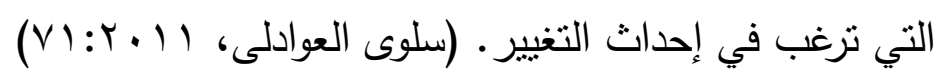
وبذلك ينضح لنا أن: الهدف الأساسي من البحث هو: "التعرف على معالجة الحملات الإعلامية التليفزيونية لظاهرة الإرهاب ".

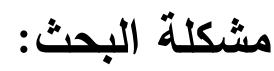
تهدف الحملات الإعلامية إلى نسويق فكرة، أو للقضاء على مشكلة، وتبدو مشكلات الإرهاب

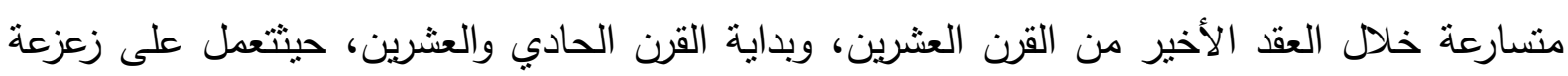
استقرار البلاد وأمنها، مما دفع الدول إلى العمل على رفع التهن الوعي لثعوبها، ويأني ذللك من خلال الإعلام ومؤسساته،التي تعمل على توخى الدقة في عرض الحقيقة، والبعد عن التهويل والتهوين.

إذن فشكلة البحث تتبلور في التعرف على ملامح صورة الإرهابيالتي تعرض في الحملات

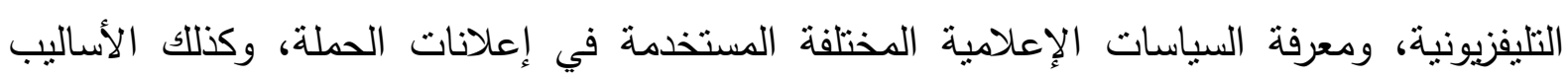
الإقناعية المختلفة المتبعة في عرض إعلانات الحملة.

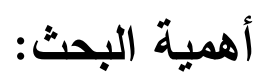

دراسة الحملات الإعلامية التي تتسق موضوعاتها مع المشكلات المجتمعية الملحة، والمطروحة

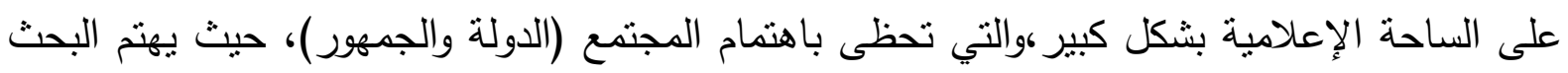

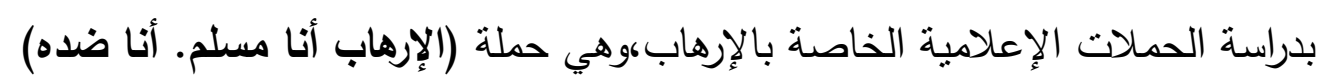

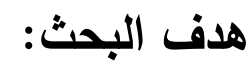
ينطلق البحث من هدف رئيس وهو : "التعرف على دور الحملات الإعلامية التليفزيونية في معالجة

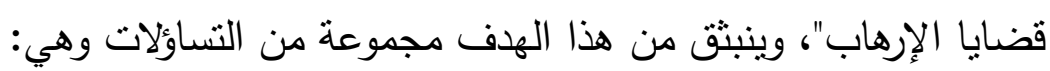


1- ما الخصائص العامة التي تتسم بها موضوعات الحملة؟ r- ما ملامح الإرهابي؛ كما تعرضها إعلانات الحملة؟ ب-ما الآليات المستخدمة في إعلانات الحملة لمواجهة الإرهاب؟

ع - ما أكثر القوالب الفنية المستخدمة في إعلانات الحملة؟ ه- ما الانطباعات والرسائل المنقولة عن الإرهاب في إعلانات الحملة؟ צ- ما الأساليب الإقناعية المستخدمة في إعلانات الحملة؟ نوع البحث: يعد هذا البحث من البحوث الوصفية التحليلية،والتي تهدف إلى وصف بناء الحملة الإعلامية، وبيان مضمونها وعناصرها.

منهج البحث:

يعتمد هذا البحث على منهج المسح بالعينة، للتعرف على صورة الإرهابي في الحملات التليفزيونية. أدوات جمع البيانات: اعتمدت الباحثة في جمع البيانات على صحيفة تحليل المضمون، التي تم إعدادها، وفقاً لأهداف

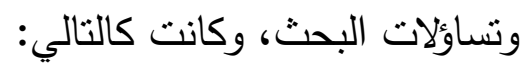
1- وحدات تحليل المضمون وهي: أ- طبيعة المادة الإعلامية: وهي الإعلان داخل الحملة، حيث بعتبر كل إعلان كوحدة أساسية من وحدات القياس. ب- وحدة الزمن: والمقصود بها المدة الزمنية التي يستغرقها كل إعلان وقد تستخدم الثنانية. r - فئات تحليل المضمون:

وتتقسم هذه الفئات إلى نوعين رئيسين هما: ا- فئات الثكل (كيف قيل) ץ- فئات الموضوع (ماذا قيل)

\begin{tabular}{|c|c|}
\hline 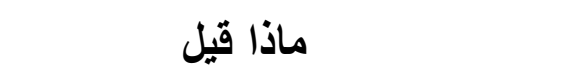 & كيف قيل \\
\hline - اللغة المستخدمة في الإعلان. & - شعار الحملة. \\
\hline -زوايا المعالجة التي تتاولتها الحملة. & - موقع ذكر ، وترديد شعار الحملة. \\
\hline
\end{tabular}




\begin{tabular}{|c|c|}
\hline -وسائط توصيل الحملات الإعلامية. & - المدة الزمنية التي تستغرقها الإعلان. \\
\hline - مداخل الإقناع التي تعتمد عليها الحملة. & - - عدد الأشخاص بالحملة. \\
\hline - أسلوب معالجة الهدف. & - القالب الفني للحملة. \\
\hline - الجمهور المستهدف (النوع - السن). & - - مقدم الحملة. \\
\hline - الاستمالات المستخدمة في الحملة. & \\
\hline
\end{tabular}

مجثمع البحث: 20 - 20

الحمالات الإعلامية التليفزيونية الخاصة بالإرهاب،والتي أذيعت على القنوات الفضائية،في الفترة من

$$
\begin{aligned}
& \text { سنه . 1. . حتى } 10 \text {. . . } \\
& \text { عنية البحث: }
\end{aligned}
$$

قامت الباحثة بعمل مسح شامل للحمات الإعلامية التليفزيونية الخاصة بالإرهاب،التي تم عرضها

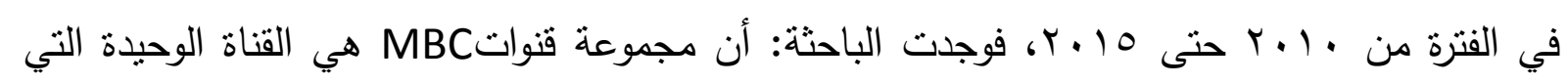
اهتمت بقضية الإرهاب وقامت بعمل حملة "الإرهاب أنا مسلم.أنا ضده"، أما باقي القنوات وخاصة|لمصرية-فقداكتفت بكتابة عبارات، أو جمل مختلفة ضد الإرهاب في أعلى الثاشة منل (كلنا ضد الإرهاب، لا للإرهاب، معاً ضد الإرهاب - تحيا مصر)، أو بعرض أفلام تسجيلية عن إنجازات القوات المسلحة ضد الإرهاب من خلال قطاع الثئون المعنوية التابع للقوات المسلحة. وقد وجدت الباحثة:أن حملة "الإرهاب أنا مسلم ـ أنا ضده" هدفها هو إيصال رأى أبناء مجتمعنا

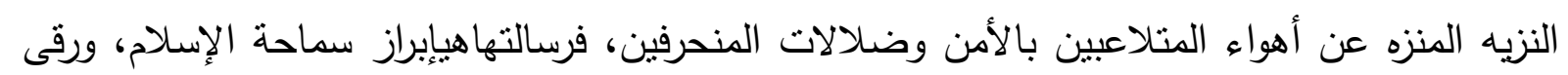
تعاليمهالتي ترفض العنف والخيانة والإرهاب، وتهدف إلى تعرية مزاعم الضالين والمضللين، وتوعية الرأي العام بتأثنرهم المدمر على المجتمعات الإسلامية والعربية والعالمية على حد سواء. وتعتبر المنظمة القائمة على هذه الحملة منظمة غير هادفة للربح، أيأنها منظمة تهدف في الأساس إلى دعم نشاط أو عدد من الأنشطة العامة، أو الخاصة دون أي مصلحة. مفاهيم البحث:

\section{ا ـ التسويق الاجتماعي: Social Marketing}

يعنى ذللك تصميم، وتتفيذ، ومتابعة البرامج المعدة لزيادة قبول الفكرة الاجتماعية، وممارستها داخل الجماعة المستهدفة، حيث يستخدم نفس المفاهيم التسويقية المرتبطة بالفكرة كمنتج، وذلك من حيث 
التخطيط والتزويج له، والترويج، وبحوث الجماهير والاتصال، وذللك بهدف زيادة معدلات استجابة الجماهير المستهدفة. (محمد فريد الصحن، مصطفى محمود: 999 (1) )

Y Media Campaigns الحملات الإعلامية

هي المحاولات التي سبق تخطيطها، وتستهدف إحداث تغييرات جوهرية في معتقدات، واتجاهات، وسلوكيات شخص، أو جماعة، أو قضية معينة من خلال وسائل الاتصال المختلفة وفى مقدمتها وسائل

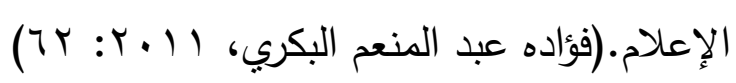

Terrorism

يعرفه عبد العزيز سرحان: بأنه كل اعتداء على الأرواح والممتلكات العامة، أو الخاصة، بالمخالفة

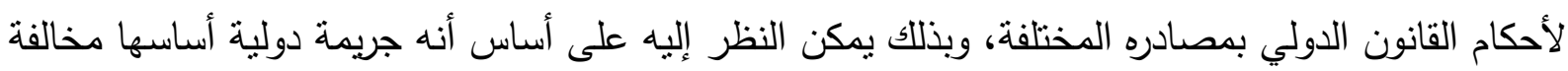

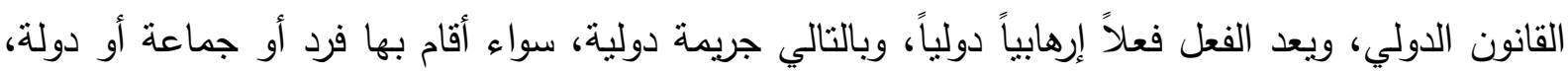

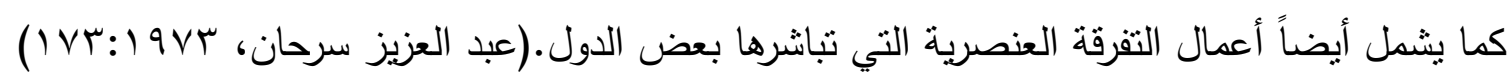
ويعرفه كذلك عصام رمضان بأنه: استخدام أو التهديد باستخدام العنف ضد أفراد، ويعرض للخطر

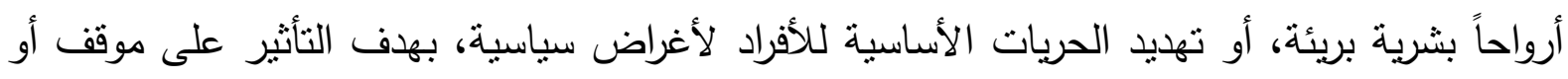

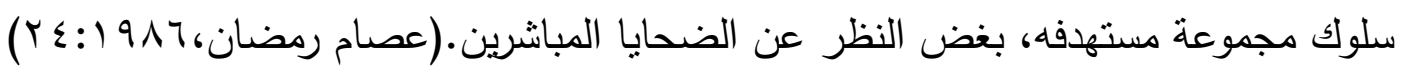

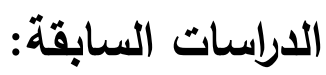

أولاً: الدراسات الخاصة بالإرهاب:

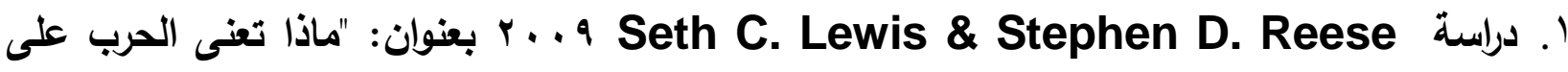

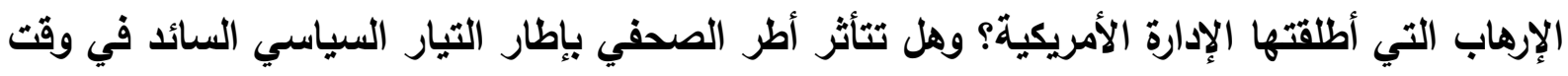

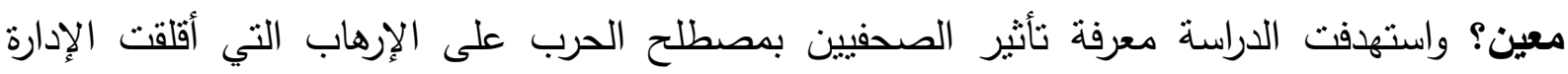

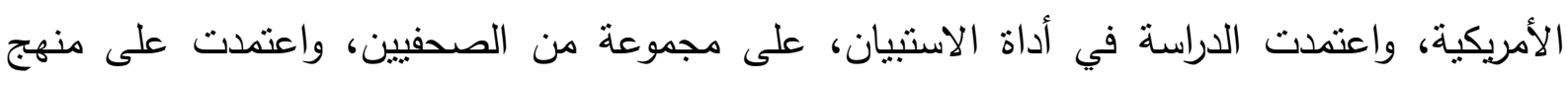

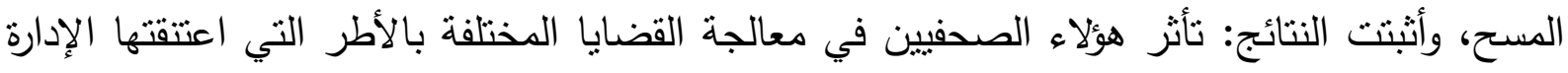

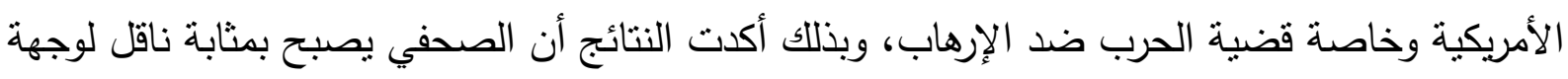
نظر القائمين على السياسة الأمريكية.(Seth C. Lewis \& Stephen D. Reese, 2009) r. دراسة علاء الثامي ج +. ب بعنوان: "دور الخطاب الايني في وسائل الاتصال في تثكيل اتجاهات

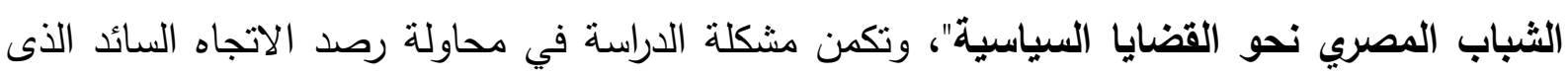

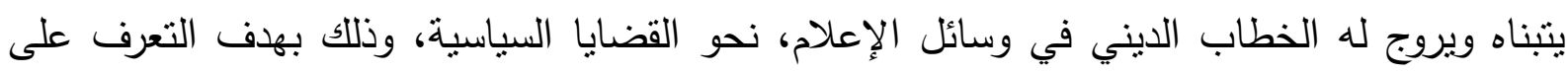

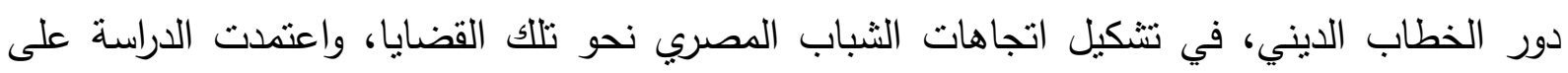
فروض نظرية دوامة الصمت Spiral of Silence، كما استخدمت المنهج المسحي والمقارن Survey 
Method

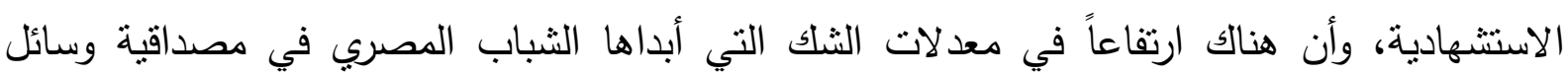

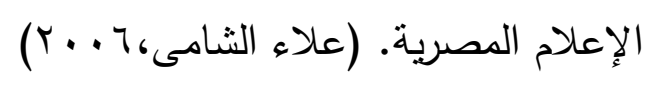

ץ. دراسة سهير عثمان عبد الحليم ؟ . . ب بعنوان: "علاقة تعرض الثباب للصحافة المطبوعة والإكترونية

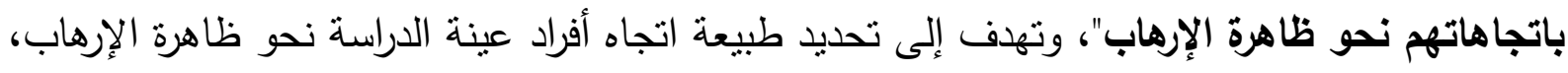

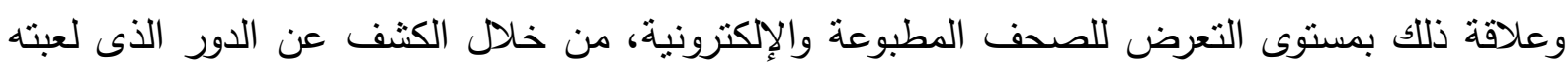

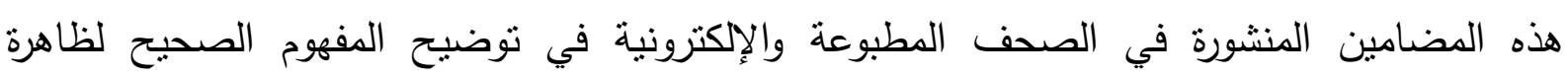
الإرهاب، ولقد استخدمت منهج المسح، كما اعتمدت على صحيفة الاستقصاء، وقد استخدمت نظرية ثراء

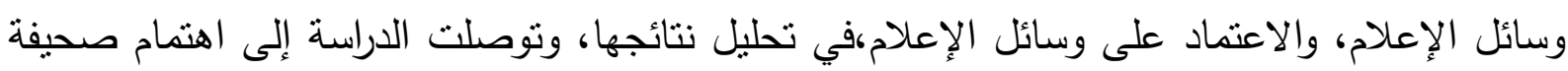

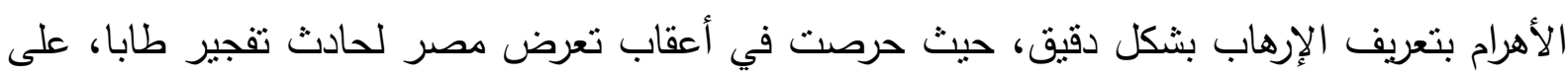

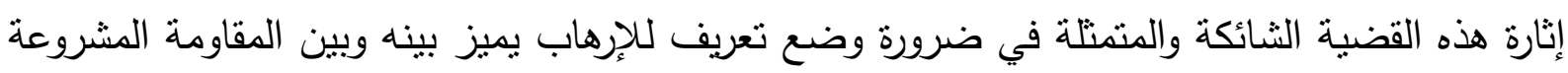

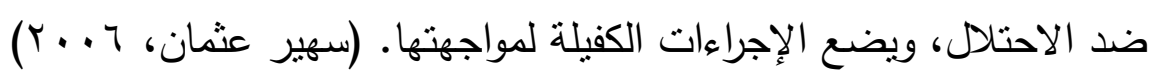

ع. دراسة أحمد فاروق رضوان ب...بعنوان: "مدى الاعتماد على وسائل الإعلام العربية والدولية،

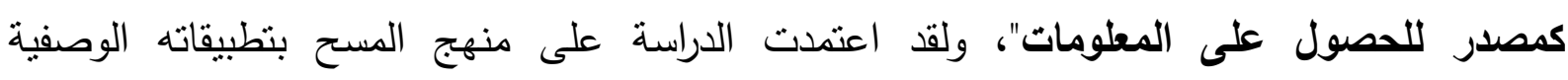

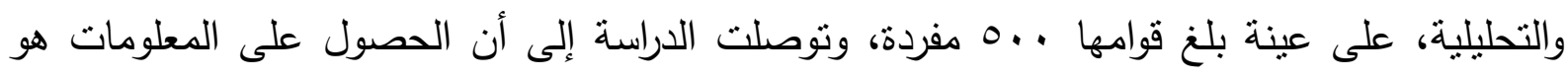

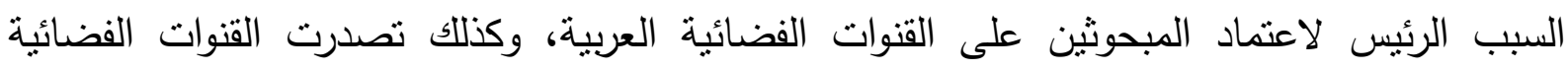

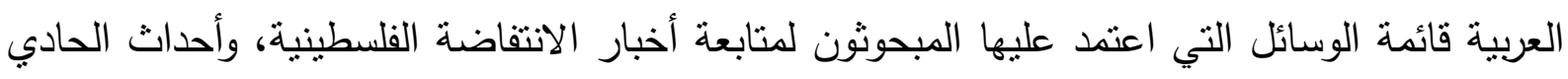

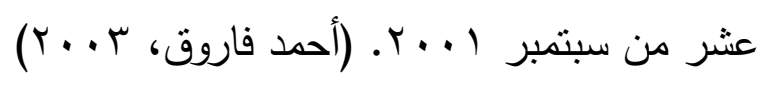

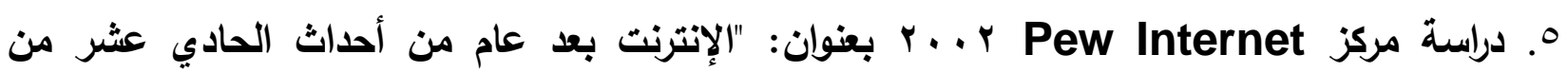

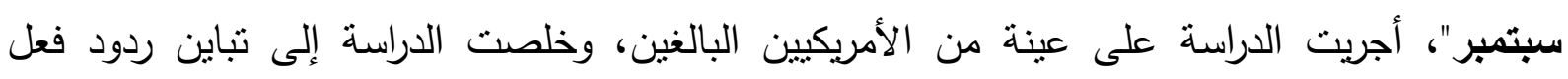
الأمريكيين حول سياسة الحكومة الأمريكية، في حجب من الإيكين، المعلومات التي يستقيد منها الإرهابيون، منل:

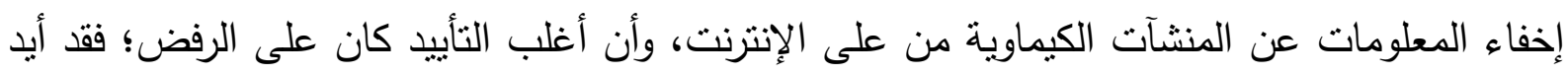
غالبية الأمريكيين الحرمان من المعلومات التي تُحتاج إذا نعلقت بالأمن القومي. (Pew internet, 2002) T. دراسة جيهان يسرى r... ب بعنوان: "اتجاهات الإعلاميين نحو تغطية الإعلام المصري لأحداث

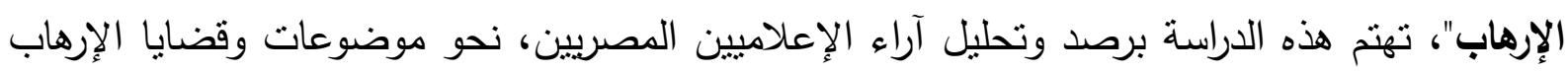

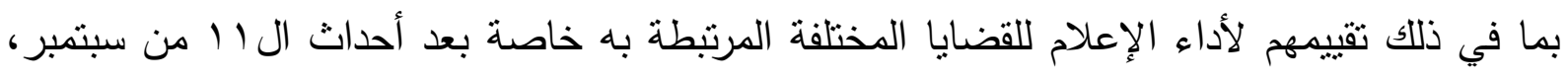

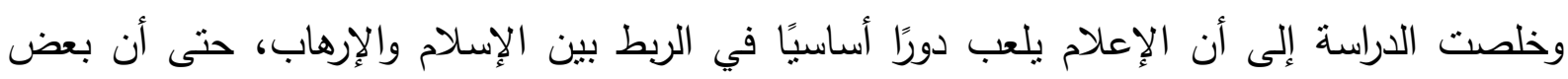

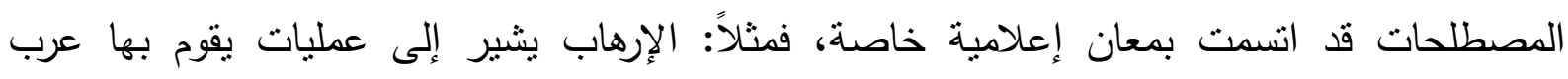

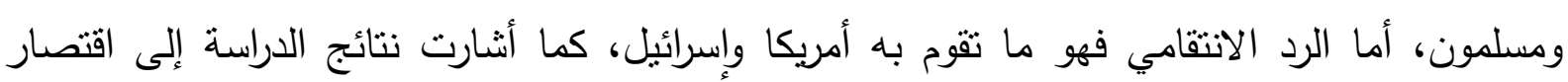


المعالجة الإعلامية لقضايا الإرهاب على تزويد المواطن بالمعلومات دون تفسيرها وتحليلها مع التركيز

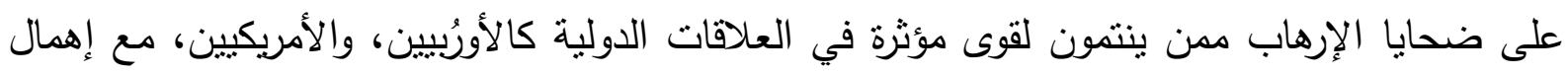

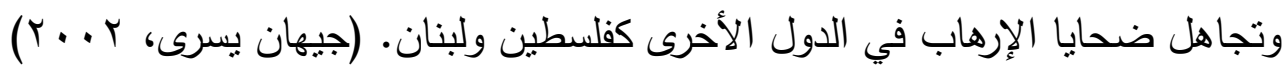

الإطار النظري: - (الن

يُعد الإطار النظري جزءًا أساسيًا في بناء أبي منهجية علمية، حيث إنه يؤثر في اختيار وبلورة

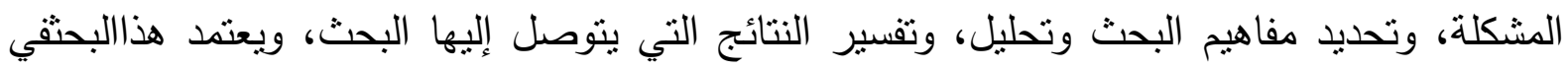

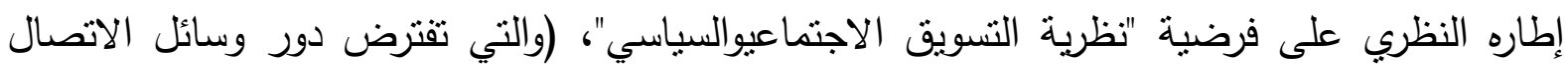
الجماهيرية في التأثير وإقناع الجمهور المنلقي من أجل تسوضيق ما يرغب فيه) حيث تهنم أساساً بالمداخل والجهود المختلفة لزيادة تأثيرات وسائل الإعلام في مجالات الجئ الحملات الإعلامية.

ويُعد النسويق الاجتماعي أداة فعالة لتغيير السلوك، حيث يقدم استراتيجية ومنهجًا مبتكرًا، لهعالجة

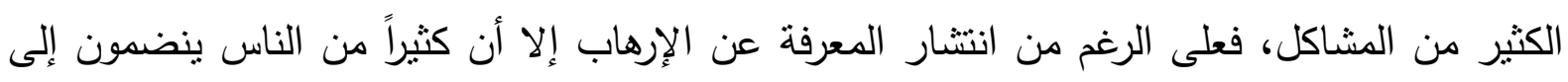

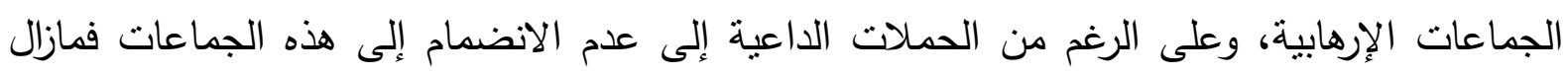

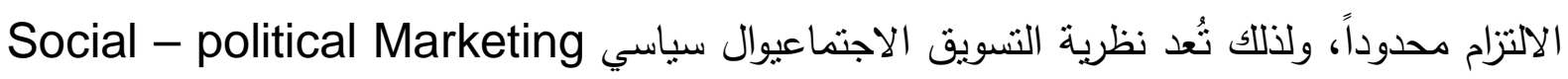

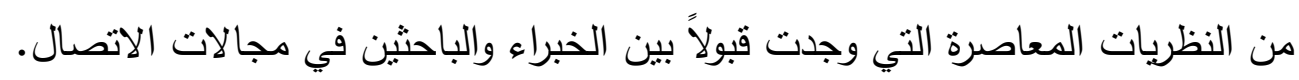
ومن هنا بدأ يظهر للنسويق الاجتماعي مجموعة من العناصر والمبادئ الخاصة به.

عناصر التسويق الاجتماعي ومبادئه:

توجد أربعة عناصر أساسية موفق ما ذهب إليه أندرسون - نشكل مسبقاً مفهوم التسويق الاجتماعي،

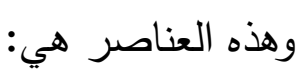

• التعليم: Education إن أول افتراض للعاملين في التسويق الاجتماعي، هو أن الناس سيغيرون

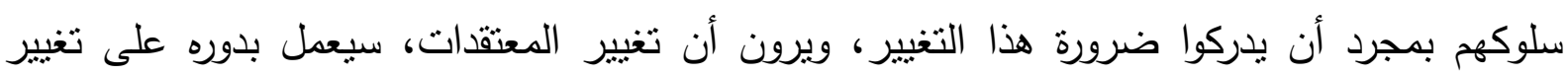

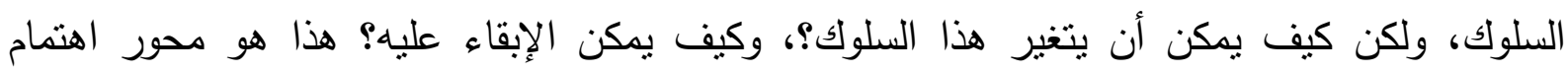

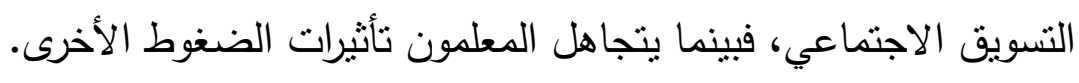

الإقتاع: Convenience ويعنى الحث والتحفيز على سلوك معين، وييحث رجال الإقناع عن

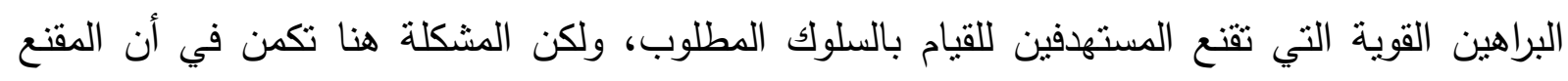

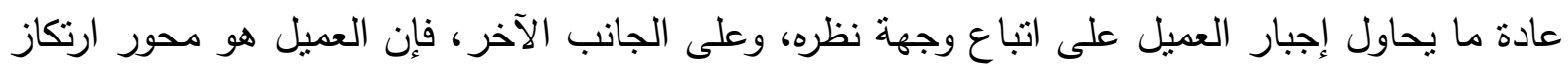
رجال التسويق الاجتماعي الذين يدركون أن التغيير سيحدث عندما ينجحون في جذب إنب العميل. • تعديل السلوك: Behaviour Correction الخطوة الأولى هي تمرين السلوك المرغوب فيه، وتتكيله، ثم تأتى المكافأة للسلوك المتغير، وذلك عندما يحدث التغيير، فالعاملون بالتنسويق الاجتماعي فرين 
على وعى كامل بأنه إذا أردت أن تكون مؤثراً وفعالا، فيجب أن تركز على تغيير السلوك لمجموعات محددة من الجمهور ، لا الجمهور بأكمله.

• التأثير الاجتماعي: Social Effect يعتبر المؤيدون لطريقة التأثثر الاجتماعي أن أكثر الوسائل فاعلية للحصول على التغيير الاجتماعي المطلوب؛ إطلاق حملات بغرض البعد عن الجماعات الإرهابية، ومع ذلك فمن الصعب الاعتماد على ذللك فقط، ولذلك فعلى المسوق الاجتماعي أن يقترح

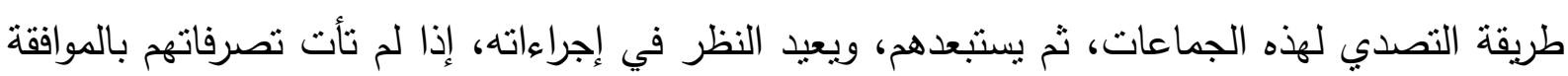
لما هو مطلوب وموضوع مسبقاً.

وتهذف النظرية إلى زيادة فاعلية حملات وسائل الإعلام القائمة على المعلومات، من خلال الفهر

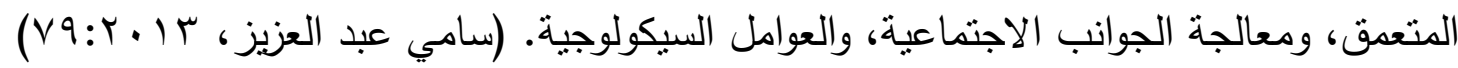
ولنظرية التسويق الاجتماعي مداخل متعددة تعكس الطرق الخاصة بتحقيق الأهداف وهي:

المداخل الخاصة بنظرية التسويق الاجتماعي:

Inducing Audience وسائل إغراء الجمهور لإدرايك موضوعات الحملة أو شخصياتها Awareness الحملات الإعلامية الدكثة التي تعد أسهل الطرق رغم تكلفتها العالية أو من خلا لأل التغطية الإخبارية

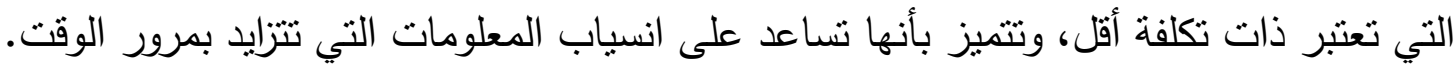
r.طرق تصويب الرسائل Targeting Messages: بمعنى استهداف الرسائل لفئة معينة، أو

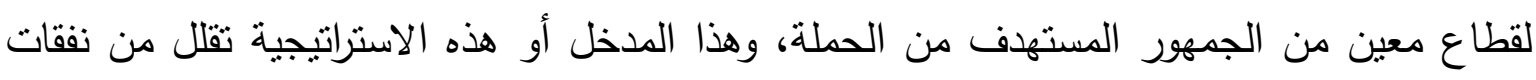

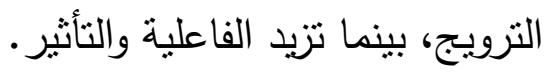

r..طرق أو وسائل تدعيم الرسائل Reinforcing Massages: أي الموجهة إلى الجمهور

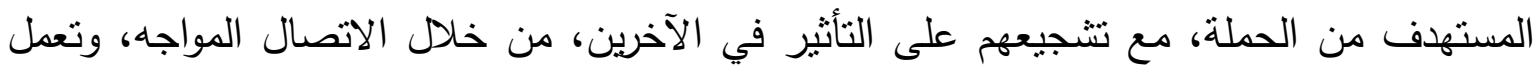
هذه الاستراتيجية على دعم العمل برسائل مشابهة، يستقبلها من قنوات متعددة.

ع.طرق غرس الصور الذهنية Cultivating Image \& Impression: بمعنى غرس الانطباعات للناس أو المنتجات أو الخدمات، ونستخدم هذه الطرق عندما يكون من الصعب زيادة

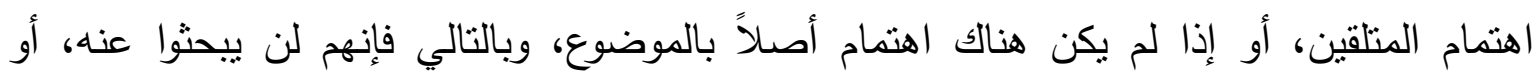

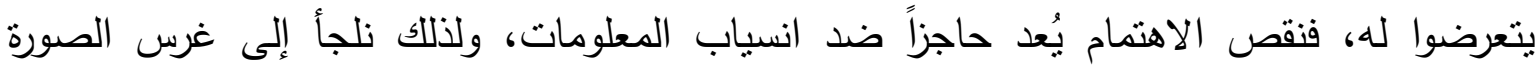
الذهنية التي يسهل التعرف عليها، ثم يتم الربط بينها وبين الموضول فئوع أو الفكرة.

Stimulating In tersest \& طرق إثارة اهتمام المتلقين وإغرائهم بالبحث عن المعلومات Inducing Information Seeking 
بناءالاهمام بالأفكار، من: الأحداث، والمواقف الدرامية، التي تثير الاهتمام بالموضوع، أو الفكرة أو الثخصية

Inducing Desired Decision Making طرق إثارة الرغبة في اتخاذ القرار أو الموقف or Positioning

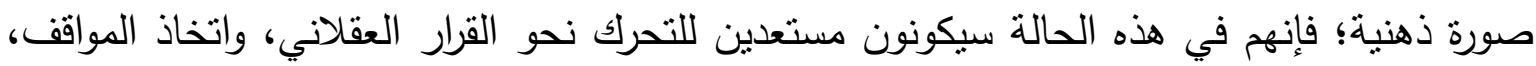

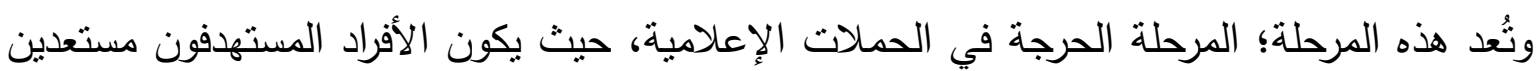
فعلاً للقيام بالفعل، أو الاستجابة المستهدفة المخططة بواسطة مخططبالحملات.

V.طرق تنشيط فئات أخرى من الجمهور Activating Audience Segments وخصوصاً الفئات المستهدفة من الحملة، وتضم هذه الطرق الفئات، والأفراد المحتملين، وهم الذين لا يجدون الفرصة رغم استعدادهم للاستجابة، حيث يحتاجون في البداية إلى الاحساس بالرضا عن الموقف الذى لإنى

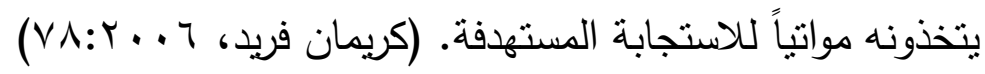

ومن خلال عرض مداخل نظرية التسويق الاجتماعي، فإننا نجد أن تلك النظرية، قد اعتمدت على العديد منالففاهيم من أهمها: التحفيز، والوعي، والاستهاف والتعزيز، والغرس والاستتارة، والتتشيط، وكذلك تستعين هذه النظرية بعدة قضايا، منها ما يتعلق بالجمهور المستهدف، وبكيفية تثويقه وباجتذابه

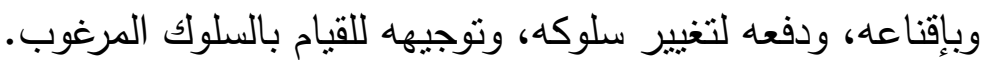

يرجع بعض الباحثين عدم إنيان أغلب الحملات لثمارها؛ بسبب عدم امتلاكها آلية استشارة الجمهور

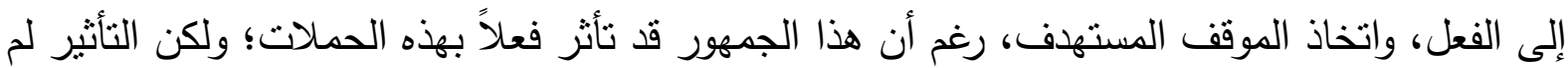

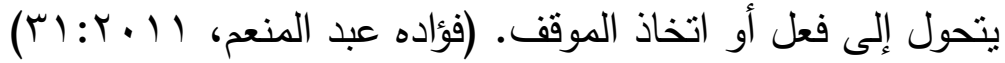
ويعد النسويق الاجتماعي بذلك مفهوماً خاصاً بالمسئولية الاجتماعية، يقوم من خلاله القائم بالتسويق بنشر فكرة، أو قيمة، مستهدفاً إحداث تأثثير معين في فكرة، أو قيمة، مستهدفاً إحداث ثأثنير

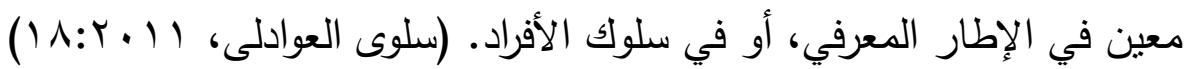

ملامح صورة الإرهابي في الحملات الإعلامية:

نتتاول هنا محتوى الحملات الإعلامية التليفزيونية الخاصة بالإرهاب، بمعنى تحليل وتوضيح مضمون الحملات، أي الصورة التي تعكسها هذه الحملات، فالحملات الإعلامية هي واحدة من أهم

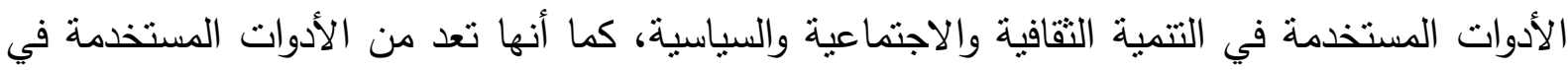
التأثير في اتجاهات الجمهور المستهدف، فهي بذللك تعد إحدى أدوات التغيير والتطوير والتتمية. وقد تم استخدام أسلوب تحليل المضمون كماً وكيفاً، لحملات ضد الإرهاب وهي حملة "الإرهاب أنا

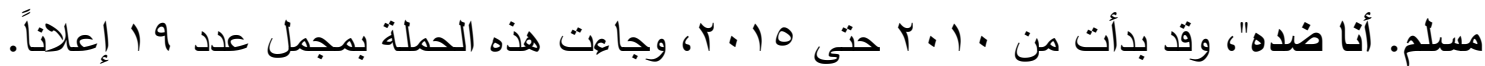


جدول رقم (1) البيانات الأساسية لإعلانات الحملة

\begin{tabular}{|c|c|c|}
\hline اسم الإعلان & تاريخ العرض & النسبة \\
\hline لا حياة حيث الإرهاب & $r \cdot 1$. & \multirow{5}{*}{$\%$ \%ч. } \\
\hline الصديق & $r \cdot 1$. & \\
\hline جحيم عائلة & $r \cdot 1$. & \\
\hline صدقة حسنة، صدقة سيئة & $r \cdot 1$. & \\
\hline عين ترقب خير من عين تدمع & $r \cdot 1$. & \\
\hline عدونا من الداخل & $r+11$ & \multirow{3}{*}{$\% 10 . \mathrm{V}$} \\
\hline صفحات من تاريخنا & $r+11$ & \\
\hline الطفل & $r+11$ & \\
\hline افتح عينيك & $r .1 T$ & \multirow{5}{*}{$\%$ \%ч.r } \\
\hline التطرف طريق نهاية الضلال & r.IT & \\
\hline الإرهابي الضال & 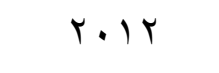 & \\
\hline الأم الحقققية & r.IT & \\
\hline الانتحاري العائد & $r \cdot 1 r$ & \\
\hline الفتتة أشند من القتل & $r \cdot 1 T$ & \multirow{2}{*}{$\% 1 . .0$} \\
\hline طريق اللاعودة & $r .1 T$ & \\
\hline اعرف عدوك & $r \cdot 1 \varepsilon$ & $\% 0 . r$ \\
\hline الزكاة & $r \cdot 10$ & \multirow{3}{*}{$\% 10 . \mathrm{V}$} \\
\hline المهرجون & $r \cdot 10$ & \\
\hline أنا برى مما تجرمون & $r \cdot 10$ & \\
\hline
\end{tabular}




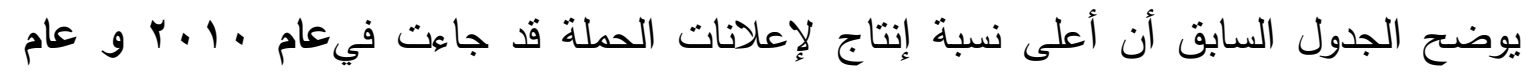

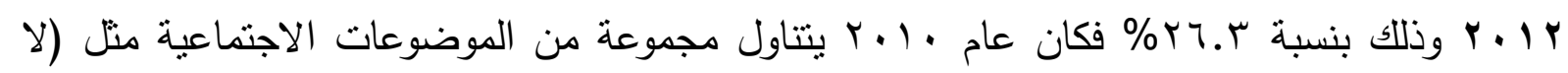

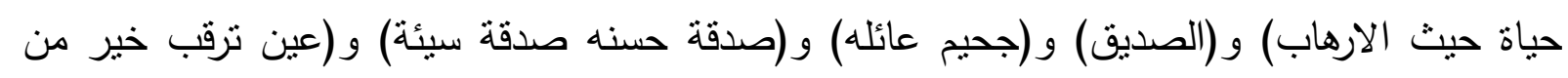

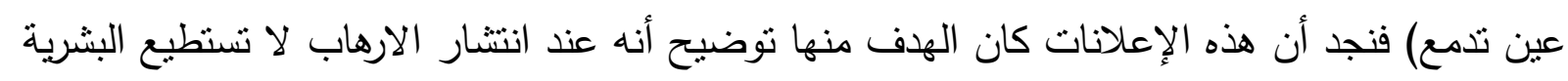

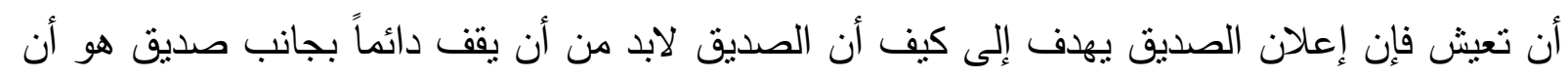

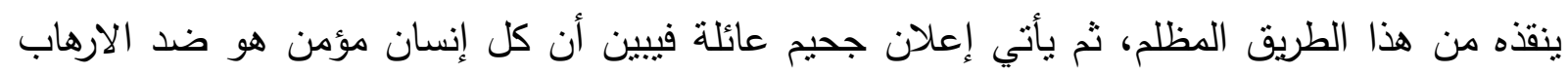

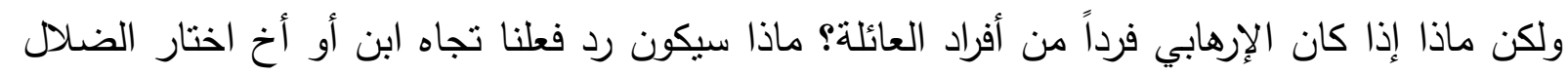

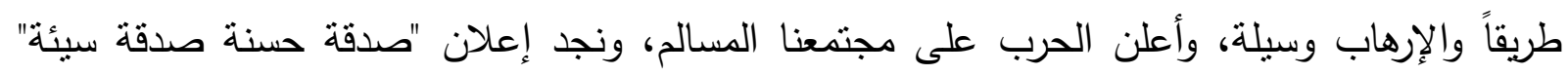

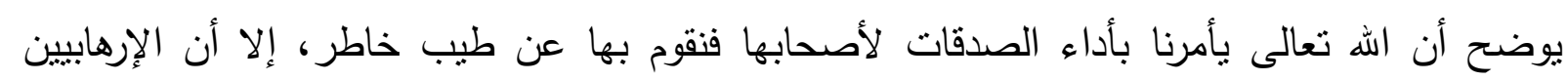

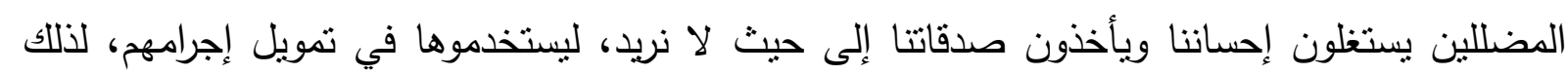
وجب علينا أن نتحقق قبل أن تتصدق.

وكذلك إعلان "عين ترقب خير من عين تدمع" فنجد أن الانترنت أصبح وسيلة للتواصل وبوابة

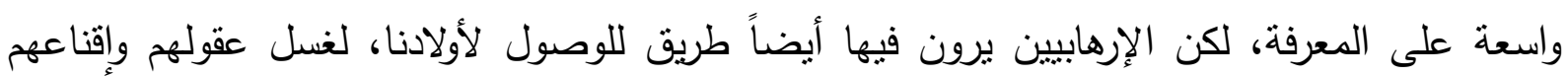

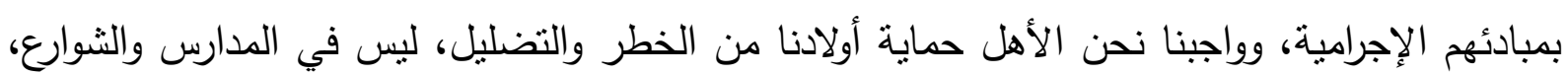

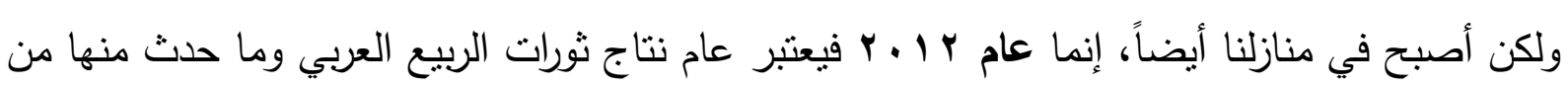

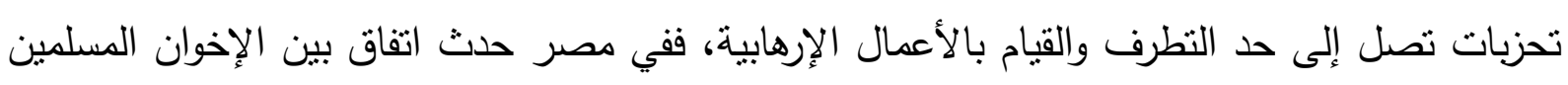

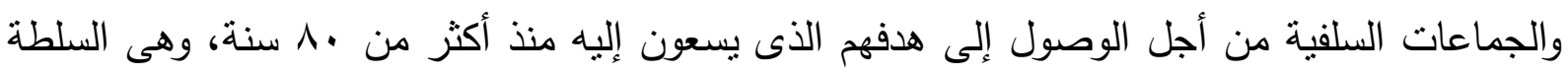

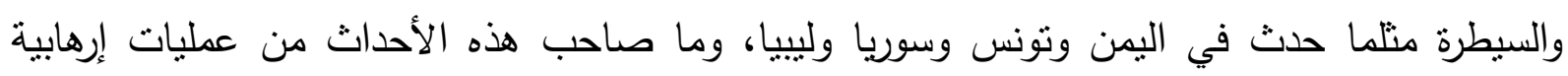

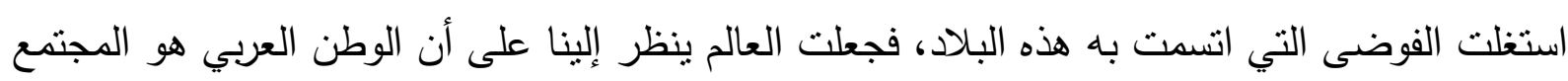

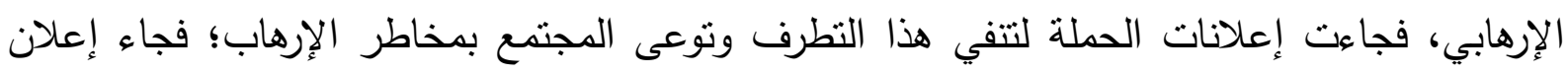

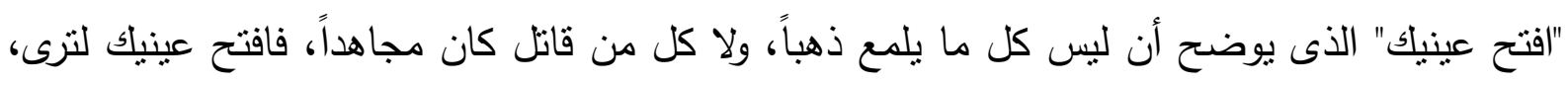

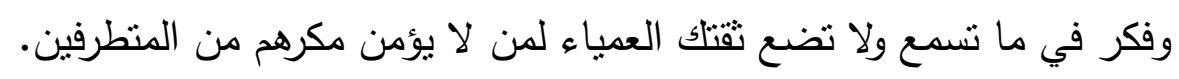

ونجد أنه نم استخدام قالب جديد وهو قالب (الاستشهاد بنماذج واقعية) فاستعانوا بالإرهابي الضال

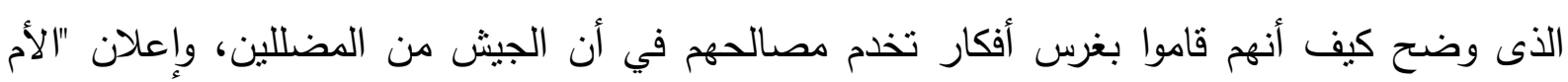

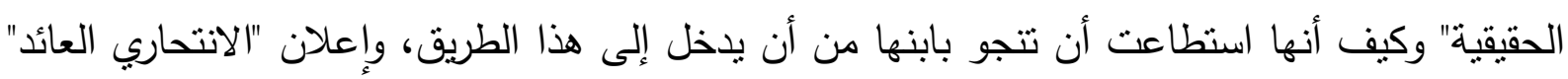

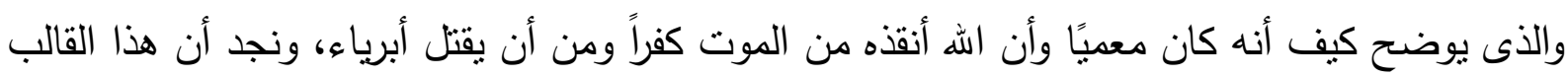

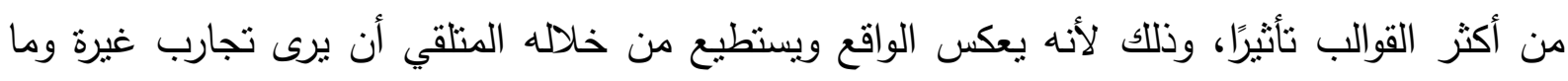

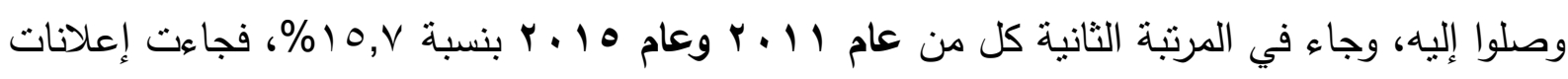

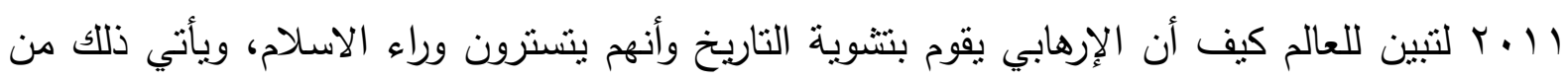

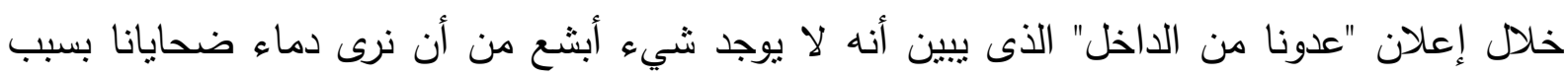


الدين، وكيف أن هذا العدو أصبح منّا ودخل فينا، وإعلان "صفحات من تاريخنا" وكيف أن العالم العربي

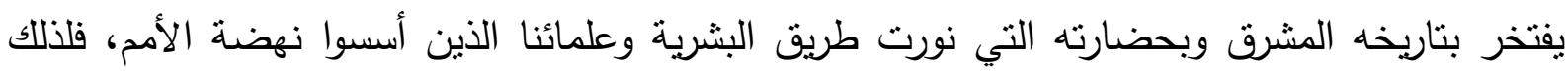

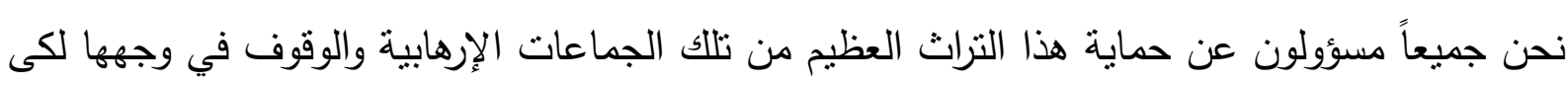
لا تشوه هذا التاريخ العظيم.

ويأني إعلان الطفل ليوضح أن الغد يتمثل في الأطفال فهل ننشئه في مجتمع أمن قائم على تعاليم

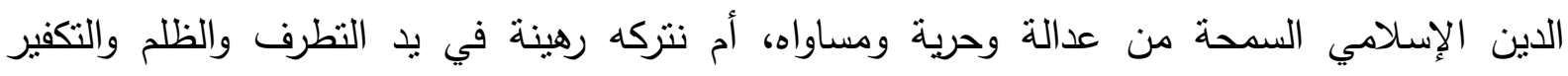

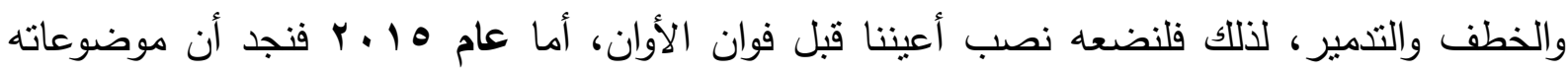

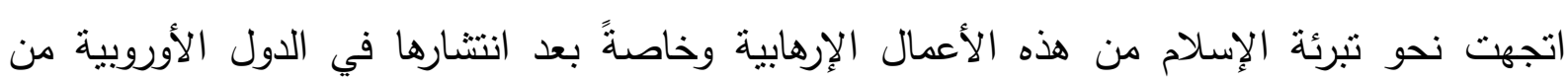

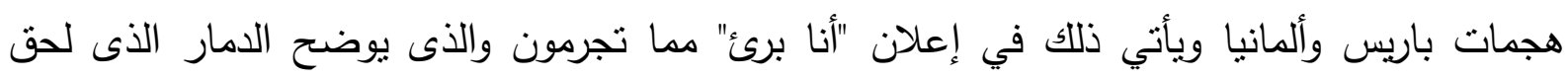

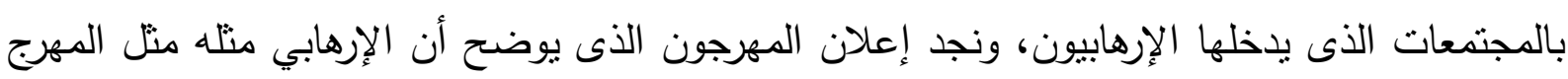

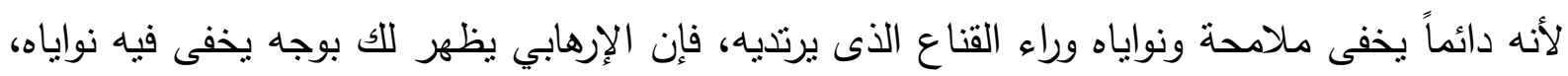

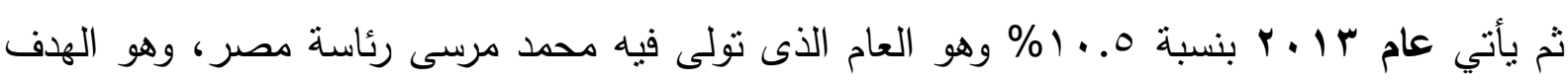
الذي كانوا يحاولون الوصول إليه، ولكن خلال هذه السنة تم دخول الجماعات الإرهابية في سيناء وبدأ

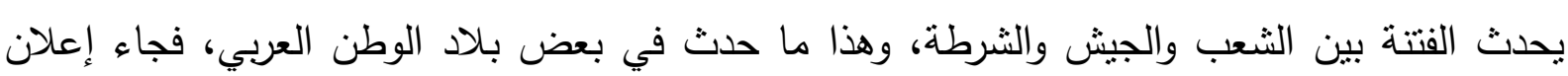

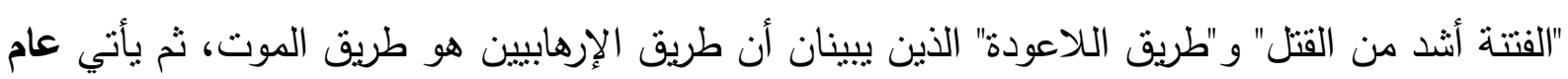

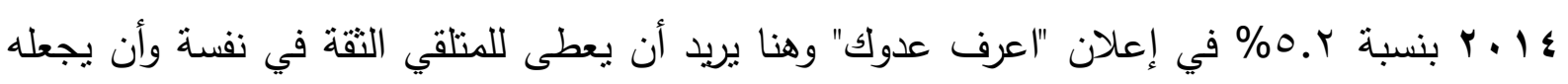

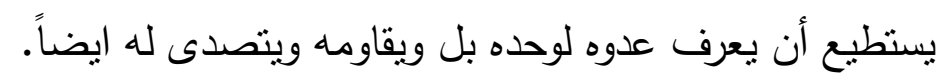

\section{أولاً: الأبعاد الثكلبة:}

ا.شعار الحملة: ويُعبر عن: أشخاص، أو رموز، أو جمل، أو عبارات قصيرة، نظهر على شاشة

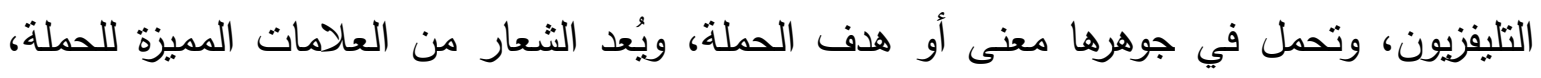

$$
\text { وينقسم إلى: }
$$

* شخص: أي وجود شخصية مشهورة مميزة للحملة. * لوجو : أي رسم مصدم خصيصاً للحملة، ويدل على الهدف من الحملة. * رمز : أب وجود، أو ظهور شكل، أو رمز مميز للحملة، يكون معناه معروفاً بالنسبة للمجتمع. * كلمة: أي الكلمة المكتوبة، أو المؤلفة، وتكون ذات معنى وتعبر عن الحملة، وتعرف باسم Slogan. 
جدول رقم (Y) شعار الحملة

\begin{tabular}{|c|c|c|}
\hline الثعار & \% & $\%$ \\
\hline لوجة & 19 & $\% 1 .$. \\
\hline كلمجوع & 19 & $\% 1 \ldots$ \\
\hline
\end{tabular}

يوضح الجدول السابق: شعار الحملة بمعنى أنواع الثعارات الموجودة في إعلانات الحملة، حيث

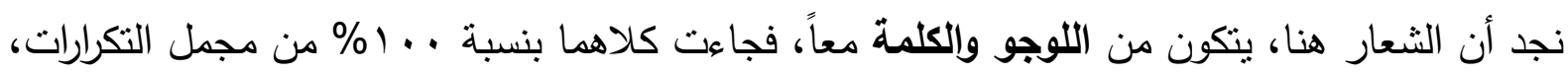
فنجد أن اللوجو هنا جاء في (الإرهاب) بخط سميك، وهو خط مناسب لعرض الثعارات على الثناشة،

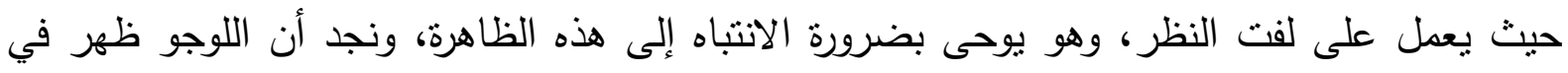

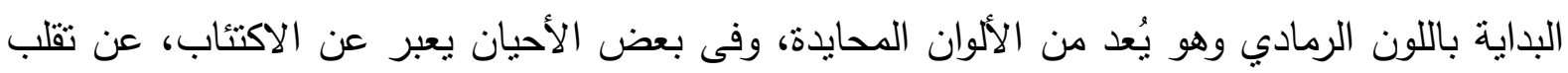

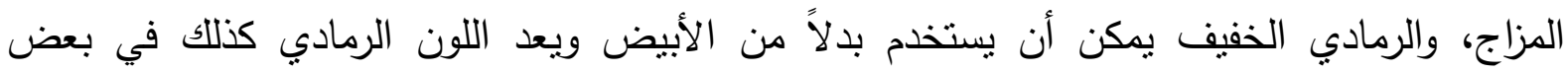

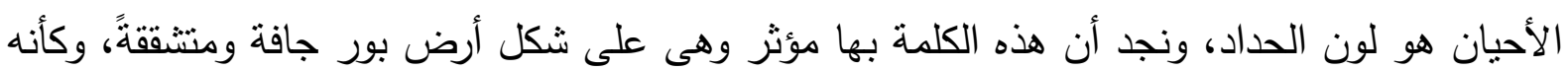

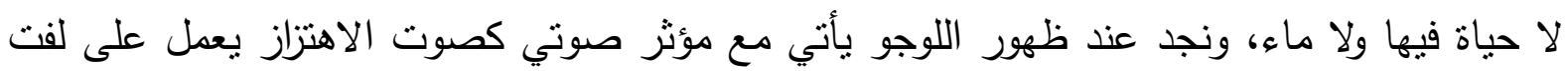

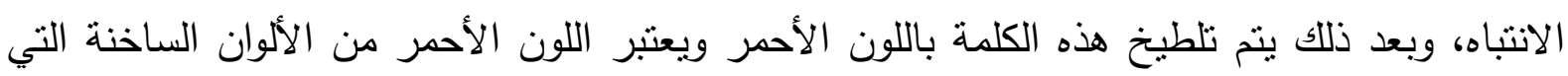

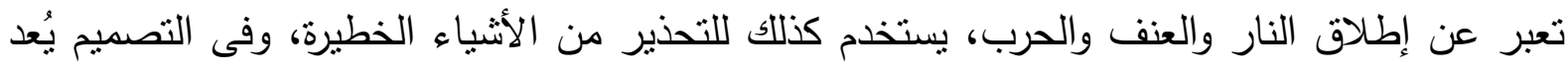
اللون الأحمر من الألوان ذات التأثير القوى،حيث نساعد على بلى جذب الانتباه، ولذلك فهذا اللون يعكس دماء الضحايا والأبرياء الناتجة من الأعمال الإرهابية، وجاءت الكلمة الأتهات هنا في (أنا مسلم. أنا ضده) وجاءت الكلمة هنا "باللون الأبيض الناصع" ويدل هذاء اللاعياء الإرهابه، في التصميمات على النقاء والنظافة والفضيلة، وبذلك فهو يعكس سماحة الدين الإسلاميوأن الاسلام ضد هذه الظاهرة،وقد ظهرت الكلمة هنا

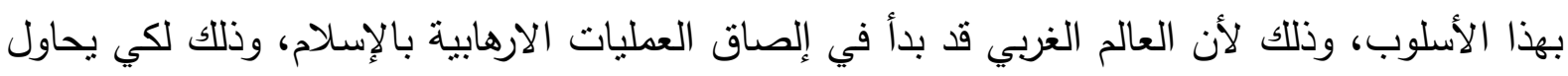

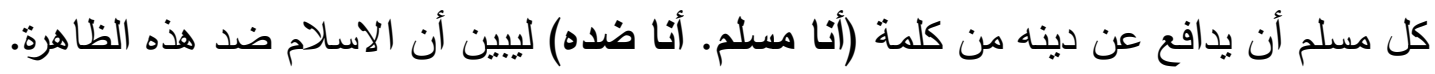
والملاحظ أن شعار الحملة هنا اللوجو والكلمة حيث جاءفي جميع إعلانات الحملة، عدا اثثين

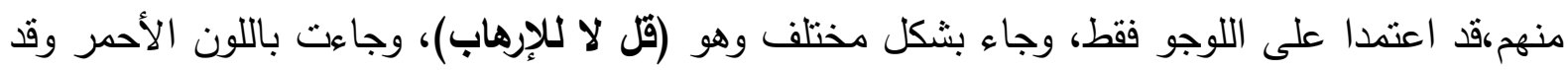
تساقطت منها دماء ودموع ضحايا الموت من الإرهاب.

r.موقع ذكر وترديد شعار الحملة: وهي أماكن ظهور شعار الحملة، خلال عرضها في كل إعلان، وهي كالتالي: * في البداية: أي التي تظهر في أول الإعلان. 
* في الوسط: أي التي تظهر في وسط الإعلان. * في النهاية: أي التي نظهر في نهاية الإعلان. جدول رقم(ץ) موقع ذكر وترديد شعار الحملة

\begin{tabular}{|c|c|c|}
\hline الموقع & ك & النسبة \\
\hline في النهاية & 19 & $\% 1 \ldots$ \\
\hline المجموع & 19 & $\% 1 \ldots$ \\
\hline
\end{tabular}

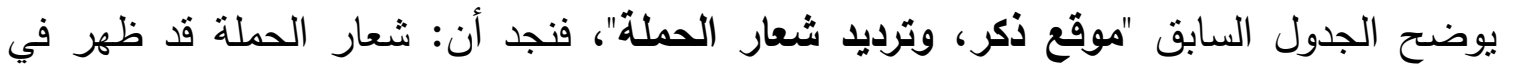

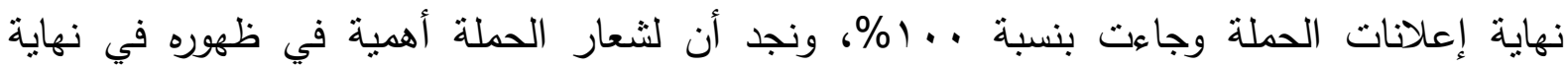
الإعلان وهو أنه عبارة عن جملة قصيرة ختامية، عادة تتضمنها جميع الإعلانات الخاصة بالحملة، حيث تتسم بالتركيز، والتلخيص، والاختصار، وتمثل خلاصة التفكير الإعلاني والتزويجي للسلوك المعلن

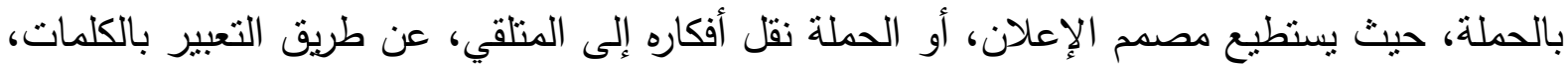
والمعاني. r.اللفة المستخدمة في الحملة: أي اللغة التي بستخدمها الأفراد في الكلام خلال الحملة، أو الجمل التي تظهر على الثانشة وتنقسم إلى: * لغة عربية: أي الجمل التي تظهر مكتوبةعلى الثانشة، وتكون باللغة العربية الفصحى. * لغة أجنبية: أي لغة أخرى غير اللغة العربية وهي لغة خاصة بالدول الأوروبية. * لهجة خليجية: أي اللهجة الخاصة بدول الخليج. * لهجة عراقية: أب اللهجة الخاصة بدول العراق.

جدول رقم (؛ ) اللغة المستخدمة في الحملة

\begin{tabular}{|c|c|c|}
\hline نوع اللفة & ك5 & النسبة \\
\hline لغة عربية & 10 & $\% \vee \wedge . q$ \\
\hline لغة اجنبية & 17 & $\% \wedge \varepsilon . Y$ \\
\hline المجموع & 19 & $\% 1 \ldots$ \\
\hline
\end{tabular}


يوضح الجدول السابق: اللغة المستخدمة في إعلانات الحملة، فنجد أن أعلى نسبة قد جاءت في اللغة

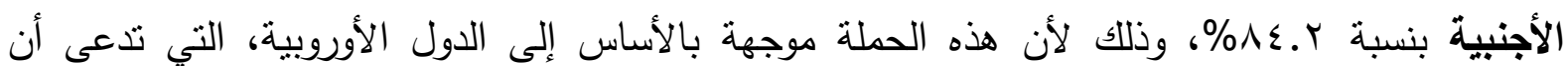
الأعمال الإرهابية وليدة الدين الإسلامي، ونجد أنها تعرض على القنوات الفضائية، إلا أننا نجد أن القناة التي تبنت عرض هذه الحملة بشكل مستمر هي: مجموعة قنوات MBC، وتتميز هذه القنوات بأن لديها مشاهدة عالية من الدول الأوروبية، وذلك لأن لها قنوات موجهة إليهه، ولأنها قنوات تتنمى إلى المملكة العربية السعودية، وهى أول الدول التي تحمل الإسلام بكل تعاليمه ومعاملاته، وقد تم ترجمة جميع الجمل التي

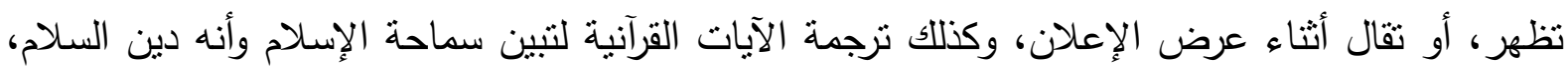
ولتوضيح تعاليمه إلى العالم بأكمله، وأن الدين الإسلامي برئ من هذه الأعمال، وأنها عبارة عن جماعات لا دين لها ولا رحمة، ثم تأتى في المرتبة الثانية اللغة العربية بنسبة و>A.9، وقد جاءت بالأكثر في ظهور "جمل مكتوبة تظهر على الثاشة في نهاية الإعلان" تلخص المقصود من كل إعلان لتوضيح وتأكيد معنى الإعلان، فنجد أن إعلان "الصحوة" قد ظهرت فيه جملة التطرف طريق نهايته الضلال، وإعلان "طريق اللاعودة" الذى يوضح أن بعض القرارات التي نتخذها في حياتتا لا نستطيع الرجوع عنها، إذا ثبت سوء اختيارها، فجاءت جملة بعض خياراتنا قد تستحيل العودة عنها، أما إعلان "اعرف عدوك" فجاءت جملة المتطرف هو عدوك، وإعلان "أنا برئ مما تجرمون" الذى يعالج ضحايا الإرهاب من الأطفال وقتلهم وتتربدهم، فجاءت عبارة عاماً بعد عام، آلاف الأطفال المسلمين؛ يقضون ضحايا متطرفين مسلمين، وإعلان "الصدقة" الذى يوضح الطرق التي تصرف فيها هذه الصدقات، فجاءت جملة بعض صدقاتنا تؤخذ إلى حيث لا نريد -تحقق قبل أن تتصدق، أما إعلان صفحات من تاريخنا، والذى يوضح العلماء المسلمين وتاريخنا، فجاءت جملة لنمنع الإرهابين المضللين من تشوية تاريخنا، أما إعلان "عين نرقب خير من عين تدمع" والذى يناقث ويوضح أهمية دور الأهل في منابعة أولادهم فقد جاءت جملة الإرهابيون عازمون على الإمن تضليل أبنائنا، وكذلك إعلان "أعداؤنا من الداخل" فجاءت جملة آلاف الابرياء يقضون ضحايا ارهابين مضللين يسترون بالإسلام، ونستتتج من ذلك أن استخدام اللغة العربية جاء لتوضيح تعاليمنا إلى الدول الأوروبية، ولتوعية المتلقين ولبيان المعنى المقصود، ولتكون الترجمة الانجليزية محددة وواضحة، حيث جميع الدول العربية تعرف اللغة العربية جيداً لأنها لغة القرآن الكربم.

جدول رقم (•) اللهجة المستخدمة في الحملة

\begin{tabular}{|c|c|c|}
\hline نوع اللغة & ك5 & النسبة \\
\hline لهجة عراقية & $\varepsilon$ & $\%$ r \\
\hline لهجة خليجية & 1 & $\% 0 . r$ \\
\hline المجموع & 11 & $\% 1 \ldots$ \\
\hline
\end{tabular}


يوضح الجدول السابق: اللهجة المستخدمة في الحملة، فنجد أن اللهجة العراقية قد جاءت بنسبة

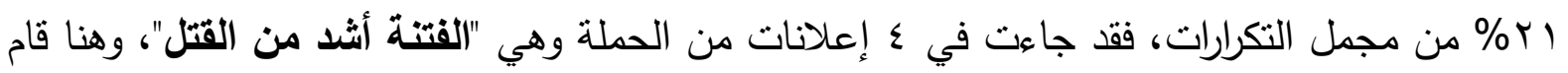

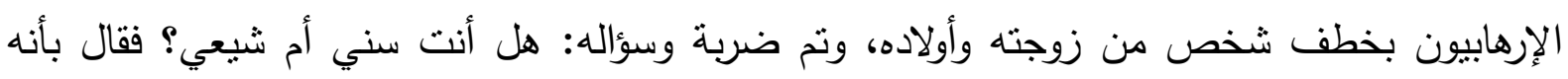

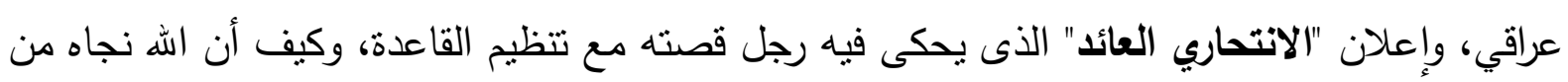
الموت، وإعلان "الإرهابي الضال"، وهو شاب يحكى قصته عندما أمسكته الثرطة العراقية، فكان التنظيم يوهمه أنهم أعداء الاسلام، ولكنهم وقت الاستجواب، نادوه لكى يصلى معهم وختم كلامه باللاهم اغفر لي

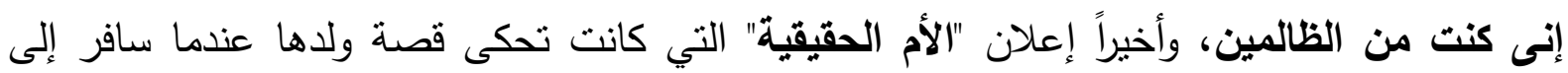

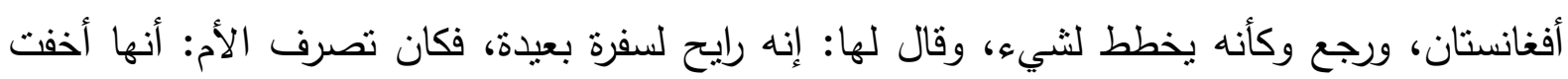
جوازه ولم بستطيع السفر واليوم، يقول لها لولاكي كنت من الخاسرين دنيا وآخرة. أما اللغة الخليجية فجاءت بنسبة r.0\%، وكان ذلك في إعلان "عين ترقب خير من عين تدمع"

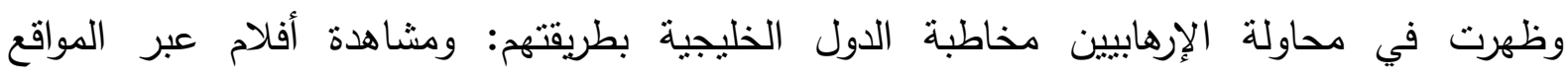

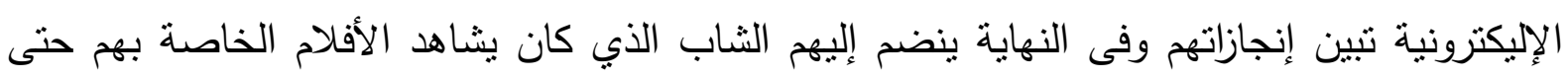

اقتنع بهم.

\section{؛. المدة الزمنية التي تستفرقها إعلانات الحملة:}

هي التي تحدد مدى الاهتمام والنركيز بالنسبة للمواد الإعلامية،أي الددة الزمنية التي يستغرقها

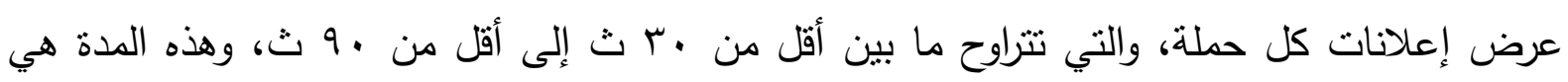
أقصى مدة، يصل إليها أي إعلان.

جدول رقم (؟) المدة الزمنية التي تستغرقها إعلانات الحملة

\begin{tabular}{|c|c|c|}
\hline المدة الزمنية & ك & النسبة \\
\hline أقل من •r ث إلى اقل من • ج ث & iv & $\% \wedge 9 . \varepsilon$ \\
\hline من · جاث إلى أقل من •9 ث & $r$ & $\% 10 . v$ \\
\hline المجموع & 11 & $\% 1 \ldots$ \\
\hline
\end{tabular}

يوضح الجدول السابق المدة الزمنية التي تستغرقها إعلانات الحملة، فنجد أن أغلب إعلانات هذه

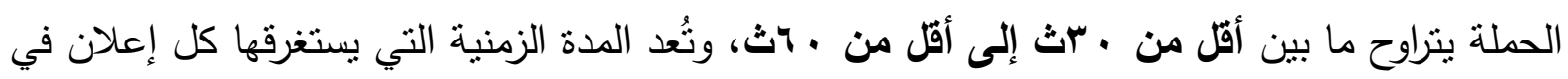

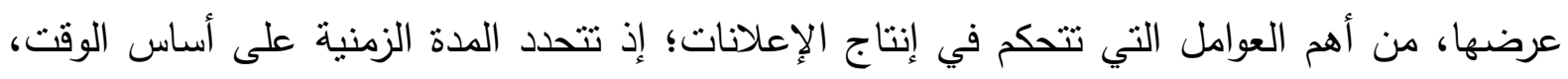

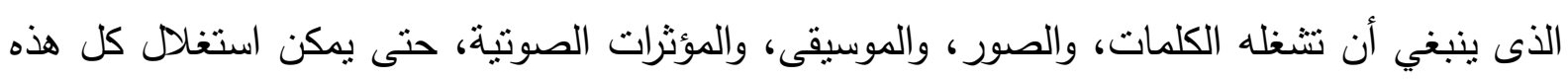


العناصر بنجاح، بما يجعل الرسالة الإعلانية تُرك بسهولة، وبسرعة، لتسنطيع تحقيق الأهداف المطلوبة

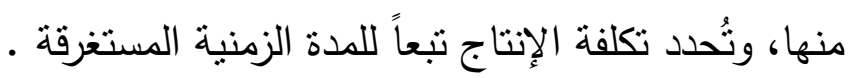
ولقد وجدنا أن أغلب هذه الإعلانات؛ لا تتعدى الدقيقة، أو الدقيقة والنصف، فنجد أن من قاموا

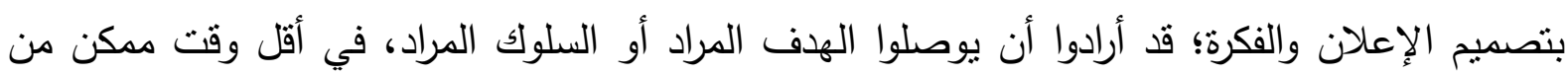
الزمن، وذللك لكي يسنطيع المنلقي مشاهدة الإعلان دون ملل، وليستطيع تذكره بسهولة. وتُعد المدة الزمنية من العوامل التي تساعد على جذب الانتباه، حيث إنها تعمل على زيادة الفرصة

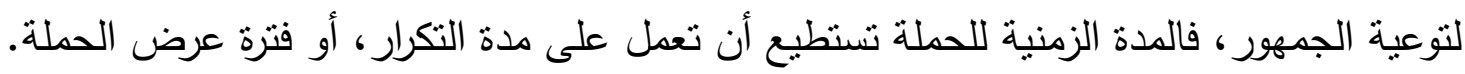
•. عدد الأثخاص بالحملة: أي عدد الأفراد المشاركين في إعلانات الحملة. جدول رقم (V) عدد الأشخاص بالحملة

\begin{tabular}{|c|c|c|}
\hline عدد الأشخاص & ك & النسبة \\
\hline من فرد إلى ثلاثة & 1 & $\% 0 . r$ \\
\hline من أربعة إلى سبعة & 0 & $\%$ rч.r \\
\hline من سبعة فأكثر & Ir & \% \\
\hline لا يوجد أنشخاص & 1 & $\% 0 . r$ \\
\hline المجموع & 19 & $\% 1 \ldots$ \\
\hline
\end{tabular}

يوضح الجدول السابق: عدد الأثخاص المشاركين في إعلانات الحملة، فنجد أن أكثر نسبة من

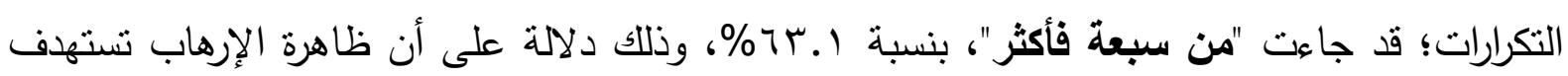

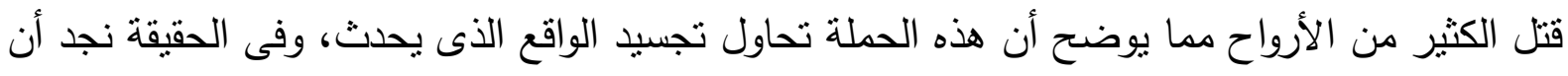

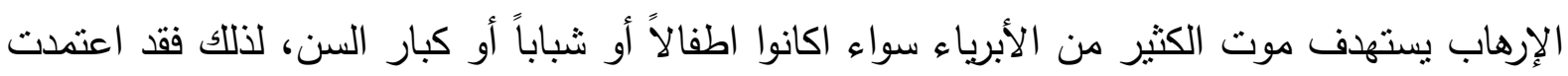

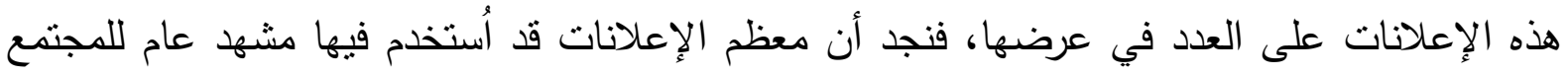

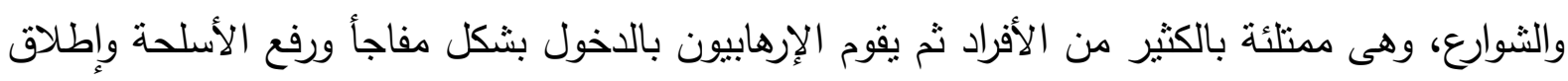
الرصاص على عامة الناس.

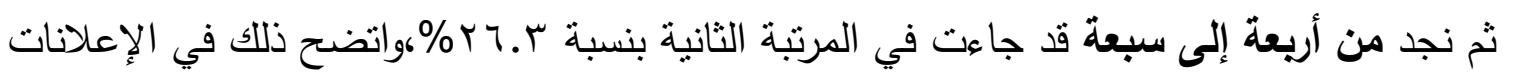

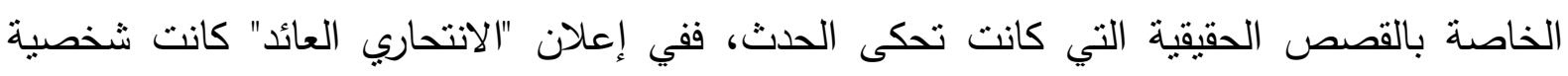

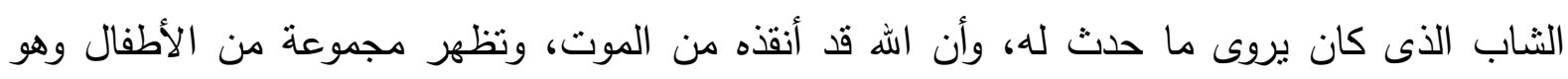


يقول: الله ما خلاني اقتل أطفال وأبرياء، وأيضاً إعلان "عين ترقب خير من عين تدمع" ظهور الأم

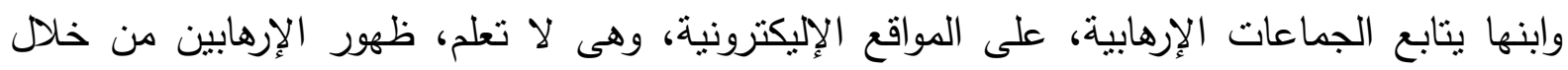

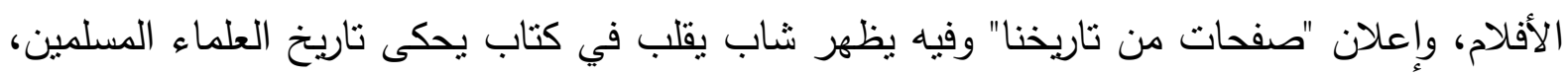

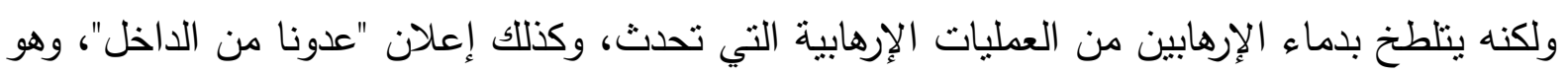

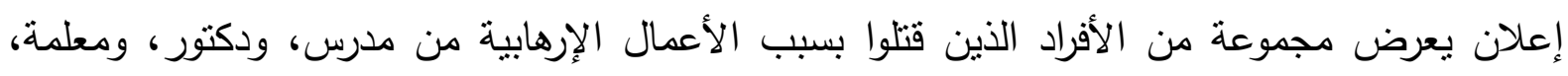

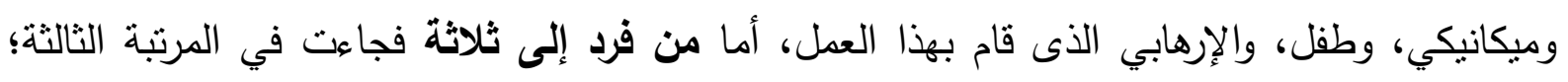

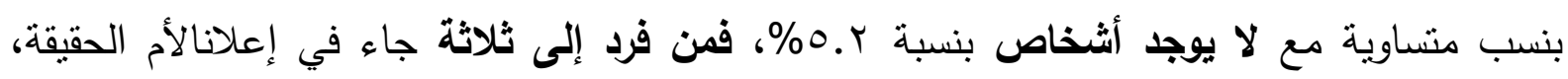

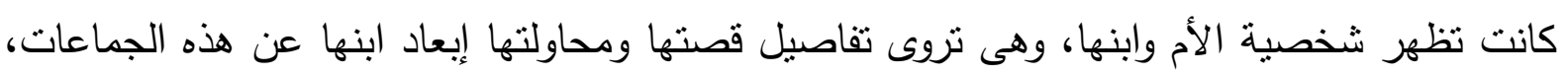

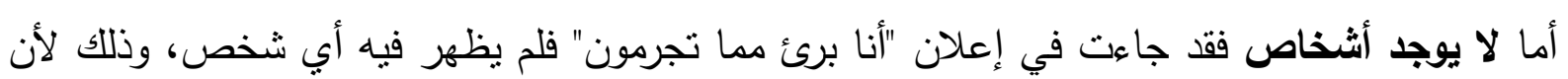

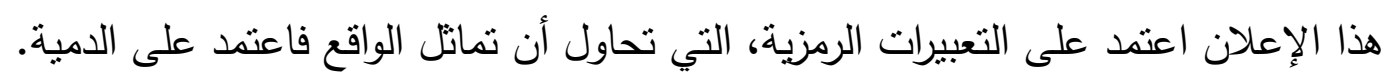
7. القالب الفني للحملة: وهو الثكل المستخدم في عرض إعلانات الحملة: دراما: بمعنى عرض الفكرة على شكل مسلسل، أو قصة. موسيقى: أي استخدام الموسيقى، أو نوع من المؤثرات الصوتية. أغنية:أي استخدام كلمات، أو شعر مصحوب بموسيقى متتاغمة.

هديث مباشر: حيث يقتصر على متحدث واحد، يوجه حديثه لجمهور الثاشة، ويعتمد بشكل كامل على شخصية المتحدث. فيتشر: وهو عرض للآراء. جرافيك: وهو عبارة عن أثكال مجسمة، أو اثخاص، تشبه الموجودة في الواقع. جدول رقم (^) القالب الفني للحملة

\begin{tabular}{|c|c|c|}
\hline نوع القالب القني & ك5 & النسبة \\
\hline دراما & $1 \varepsilon$ & $\%$ VT.T \\
\hline موسيقى & 19 & $\% 1 \ldots$ \\
\hline حديث مباشر & $r$ & $\% 10 . V$ \\
\hline جرافيك & 1 & $\% 0 . r$ \\
\hline المجموع & 19 & $\% 1 \ldots$ \\
\hline
\end{tabular}




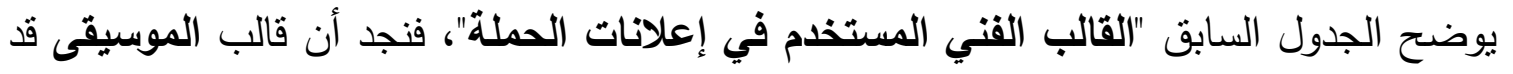
جاء كأعلى نسبة تكرارات بنسبة . . 1\%، وذلك لأن جميع الإعلانات قد اعتمدت على الموسيقى، كمؤثر صوتيفي كل الإعلانات، لأن الموسيقى تؤثر في وجدان المتلقي، ولا يوجد أحد مختلف على الإنى تأثثر

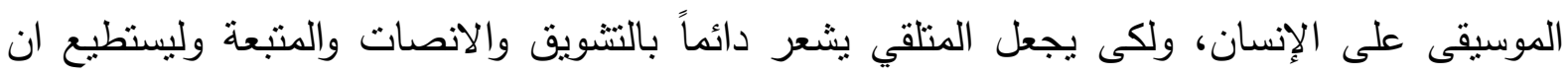

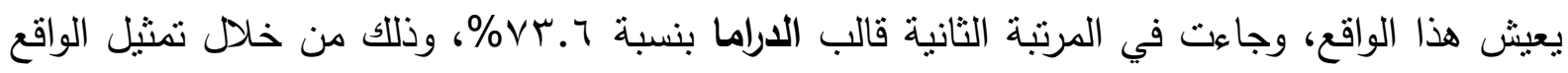

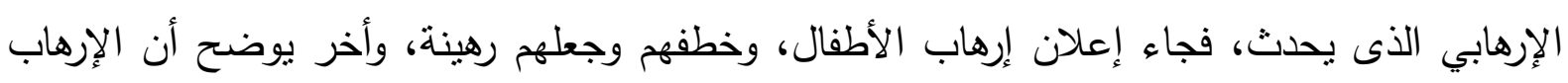

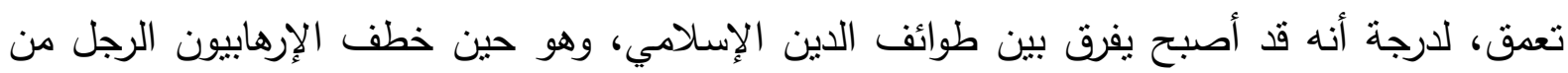

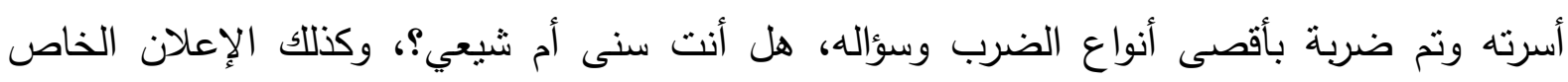

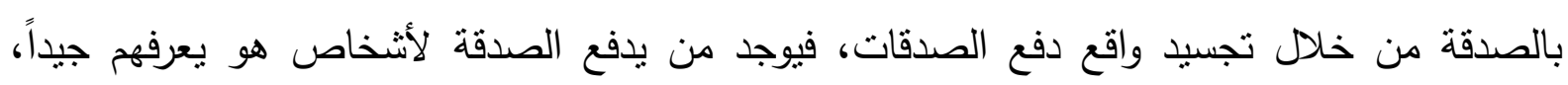

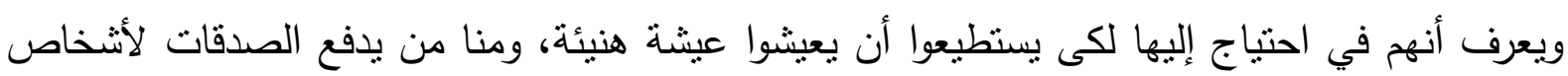

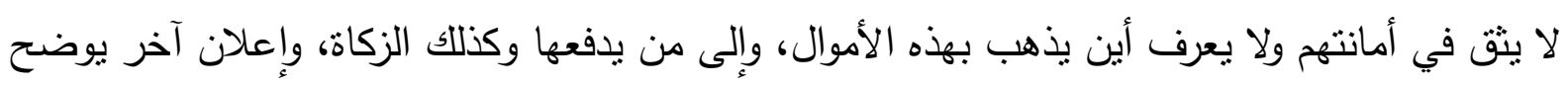

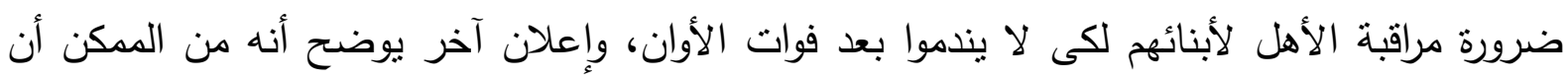

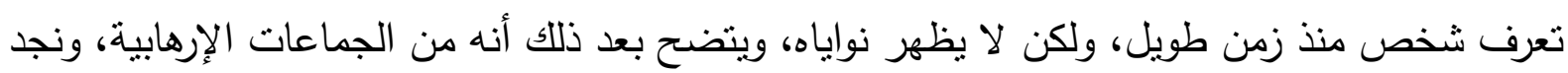

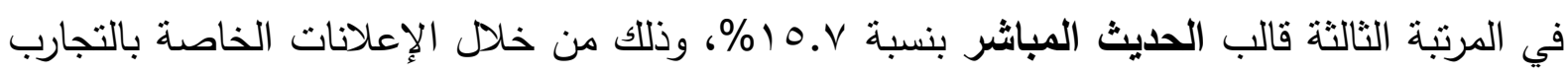
الثخصية، فنجد الأم تحكى ما حدث مع ابنها وآخر يروى عن الانتحاري العائد، وما حدث لها له، وكذلك البك

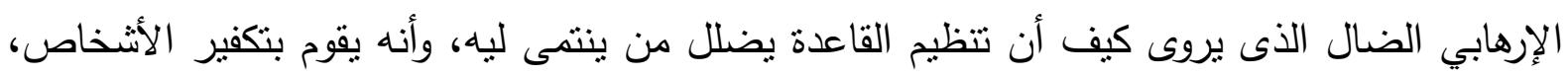

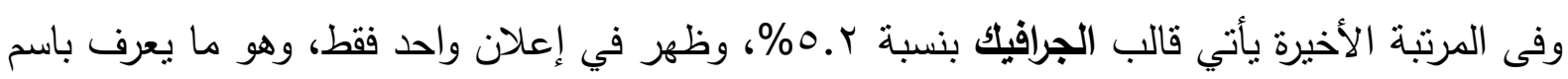

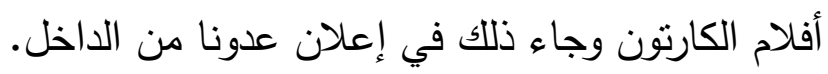

ونجد أن قالب الجرافيك من أكثر القوالب جذباً لانتباه المشاهدين، حيث تعمل على جذب انتباه

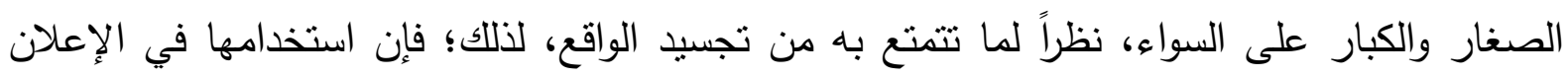

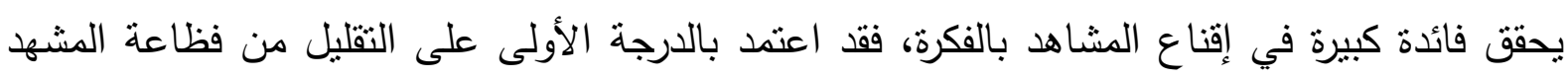

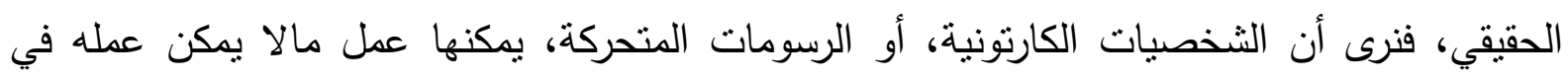

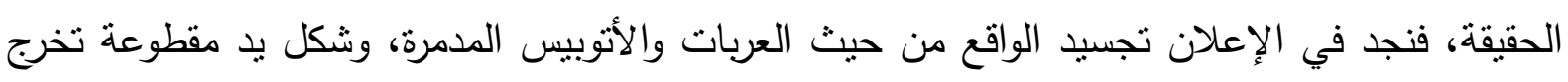

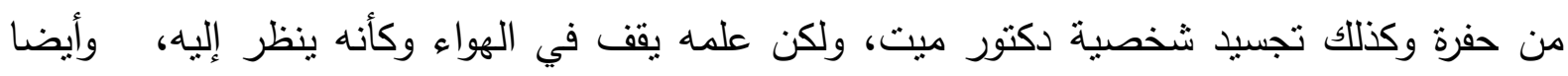

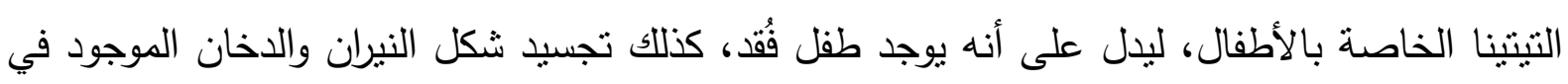
المكان بعد حدوث الانفجار .

\section{ثانياً: وسائط توصيل الحملات الإعلامية:}

1. مقدم الحملة: هو الثخص الذي يقوم بعملية الاتصال، أي بإرسال الأفكار إلى الجمهور، وينقسم إلىى: 
* من حيث التخصص:

• شخصية مشهورة: أي شخص معروف لدى المجتمع، يحظى بإعجاب الكثيرين فأصبح معروف

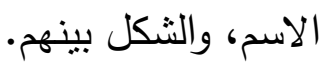

• شخصيات عامة: أي شخصيات غير معروفة للمجتمع.

• خبير متخصص في موضوع الرسالة: أب شخص متخصص في مجال معين، يقوم بتقديم الخبرة

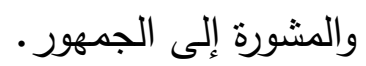

* من حيث النوع: رجل - امرأة

جدول رقم (9) مقدم الحملة

\begin{tabular}{|c|c|c|c|c|c|c|}
\hline من حيث & \multicolumn{2}{|c|}{ شخصيات عامة } & \multicolumn{2}{|c|}{ شخصيات } & \multicolumn{2}{|c|}{ المجموع } \\
\hline ذ ذكر & $\Lambda$ & $\% \leq r .1$ & صفر & صفر & $\Lambda$ & $\% \leq Y .1$ \\
\hline أنثى & 1 & $\% 0 . r$ & صفر & صفر & 1 & $\% 0 . r$ \\
\hline الاثنان معاً & 1 . & $\% \circ$ or. & صفر & صفر & 1 . & \%०r.7 \\
\hline المجموع & 19 & $\%$ & صفر & صفر & 19 & $\% 1 \ldots$ \\
\hline
\end{tabular}

يوضح الجدول السابق: "مقدم الحملة" حيث يعد مقدم هو القائم بالاتصال، وهو الثخصية المهمةفي التأثير ، ويفسر علماء النفس ذلك؛ بأن الجمهور يعتبر اجتماعياً ومدركاً لحاجاته ورغباته، ولكن يبقى لكل فرد على حده تركيبته النفسية المتميزة ، فلو تعرض شخصان لنفس المؤثر فلن بسلكا بالضرورة نفس المسلك، وذلك بسبب الاختلاف في الخبرة الثخصية، والمقدرة العقلية، والتركيب العاطفي، ولذا فإن مقدم الحملة يستطيع أن يحدد الطرق التي من خلالها يستطيع الفرد تقبل الفكرة وتتفيذها، ويكون لله تأثثرفي الجمهور المتلقي، فنجد أنه من حيث التخصص فقد جاءت أعلى نسبة في الشخصيات العامة حيث جاءت بنسبة V. 9\%٪، لأن هذه الحملة قد اعتمدت أساساً على الثخصيات العامة المتواجدة في الثارع، مع اختلاف المستويات الطبقية لهم، وهذا ليوضح أن الإرهاب يأتي بأشخاص لا ذنب لهم،

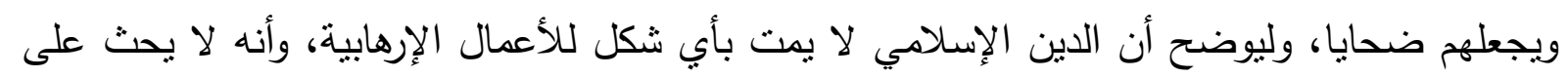
القتل ولا الحرب او هلاك المجتمع، أما بالنسبة إلى مقدم الحملة من حيث النوع فجاءت أعلى نسبة في (الاثنان معاً) بنسبة ج. ro\%، مما يؤكد أن دور المرأة والرجل منساوٍ في التأثنر وأن لكل منهما دوراً في 
المجتمع، وليبين أن الدين الإسلامي بساوى بينها دائماً، وأن الأعمال الإرهابية لا تتظر إلى رجل، أم امرأة، ولكنهم يريدون من يعمل لصالحهم.

\section{r. نوايا المعالجة التي تثناونها الرسالة:}

هي مرحلة من مراحل بناء الحملة، وفيها يتم وضع التصور للحملة لتقديمها للمشاهد، حتى يتم توصيل المعلومة، أو الفكرة بصورة بسيطة -أي الطريقة المستخدمة في طرح الفكرة -تتقسم إلى: • منظور تتموي: وهو منظور يعتمد على الحث على إظهار بلدك وتتمينها. • منظور ديني: وهو منظور يعتمد على إظهار تعاليم ومعاملات الدين الإسلامي. • منظور وقائي: وهو منظور يعتمد على عرض كيفية الوقاية، من هذه الجماعات والبعد عنهم. • منظور ثقافي: وهو منظور يعتمد على إظهار ثقافة الجماعات الإسلامية وتثافة الإسلام. منظور سياسى: وهو منظور يعتمد على إظهار أن هذه الجماعات هي جماعات سياسية، وليست دينية.

جدول رقم ( • 1) زوايا المعالجة التي تتناولها الرسالة

\begin{tabular}{|c|c|c|}
\hline زوايا المعالجة & ك & $\%$ \\
\hline من منظور تتموي & r & $\% 1 . .0$ \\
\hline من منظور وقائي & $\pi$ & $\%$ ฯ人. \\
\hline من منظور ديني & 14 & $\%$ ฯ人. \\
\hline من منظور ثقافي & 19 & $\% 1 \ldots$ \\
\hline من منظور سيأسى & 0 & $\%$ หч.น \\
\hline المجموع & 19 & $\% 1 \ldots$ \\
\hline
\end{tabular}

يوضح الجدول السابق "زوايا المعالجة التي تناولتها رسائل الحملات"، حيث نجد: أن المنظور

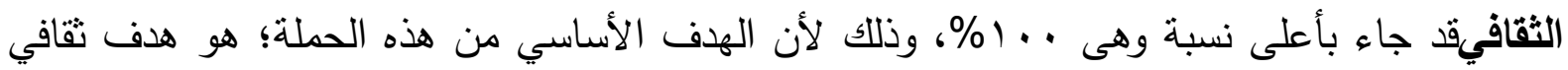

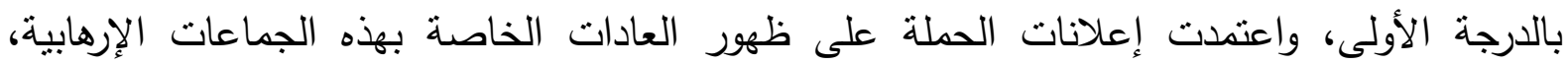
المنمتلة في ظهور تعليم الأطفال إمساك السلاح والضرب به، وأيضاً خطف الأطفال وجعلهم رهينة،

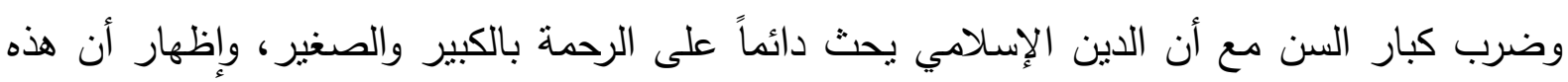


الجماعات حين تجد من سيقع أو أن أحد سوف يلحق به خطر لا تقف بجانبه ولا تسانده، بل تجعله يقع

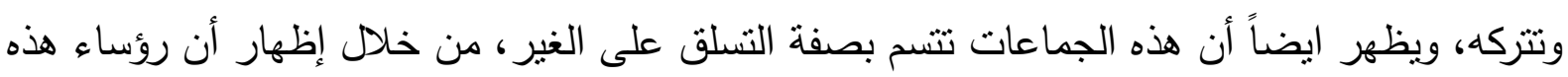

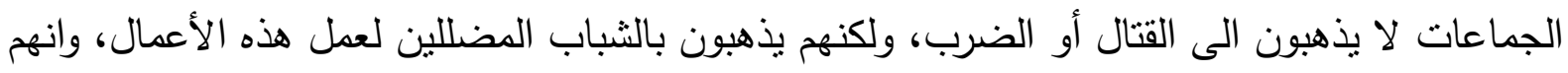

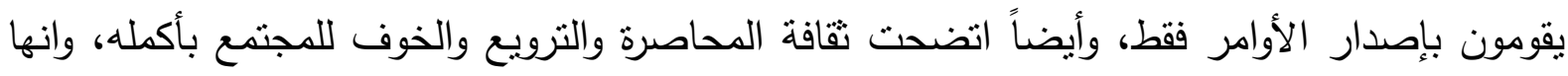

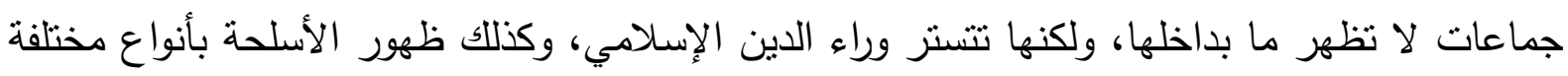

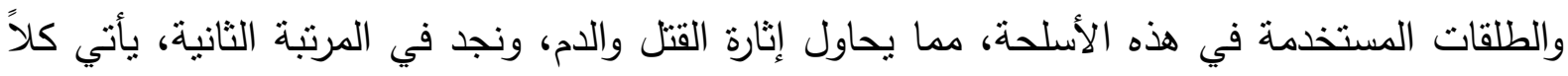

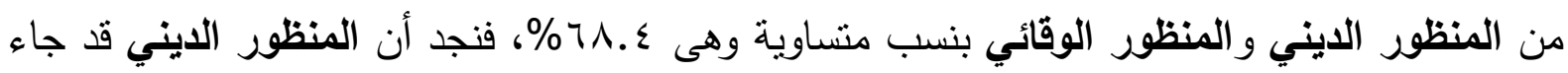

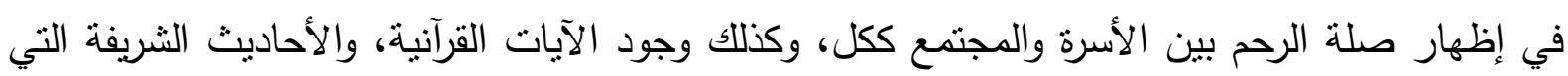

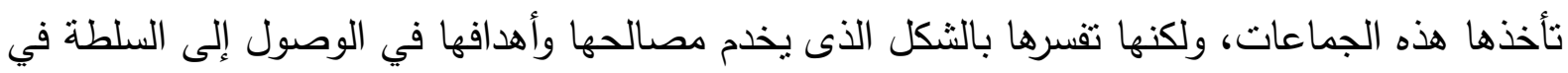
آلاف الأبرياء يقضون ضحايا إرهابيين مضللين يتسترون بالإسلام، وكذللك ظهور الأطفال وترويع

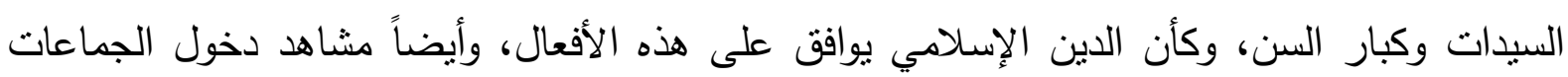

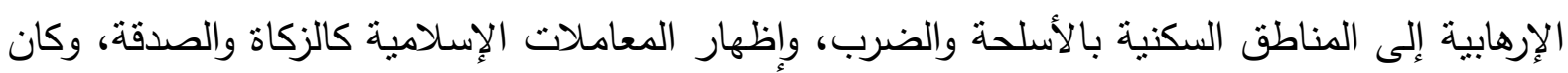

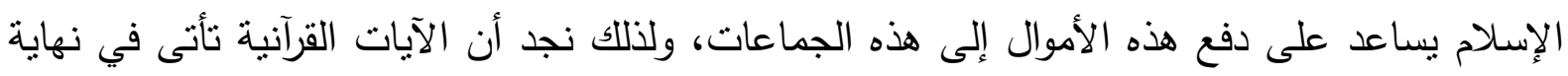

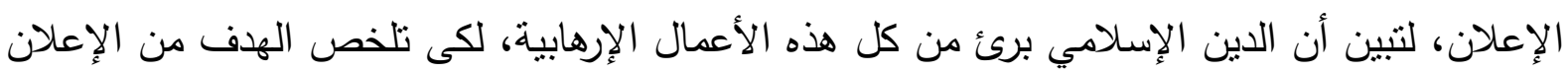

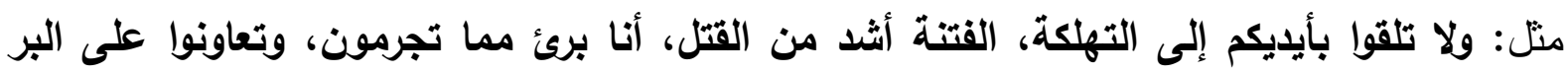

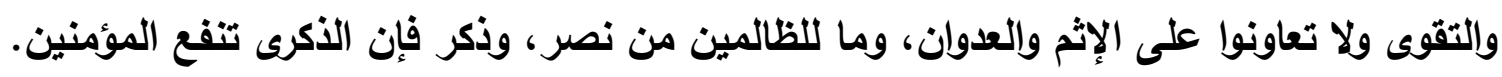
أما المنظور الوقائي فينبع من الهذف الأساسي لهذه الإعلانات، حيث تقي الثباب والفئات

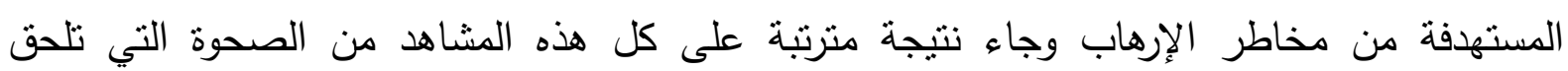

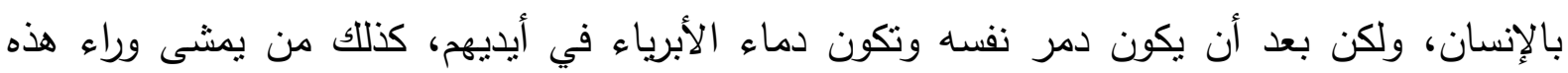

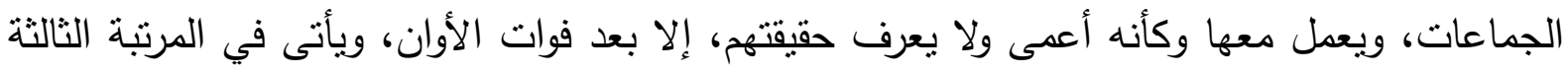

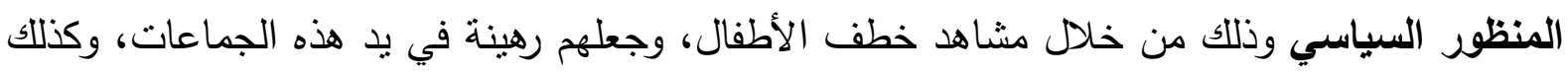

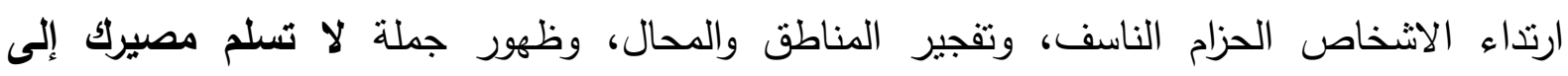

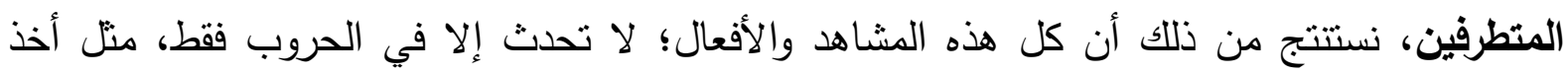

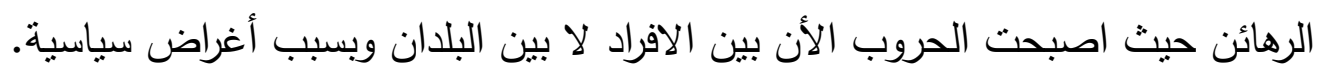

\section{r. مداخل الإقتاع التي تعتمد عليها الرساية:}

1. مداخل الإقتاع: وتعنى محاولة إقتاع فرد، أو جماعة بفكرة، أو بقضية محددة، وتتقسم إلى:

• مدخل ديني: أي الإقناع عن طريق الموضوعات الدينية.

• ددخل ثقافي: أي الإفناع عن طريق إظهار طبيعة السلوك.

• مدخل اجتماعي: أي الإقناع عن طريق إظهار القضية، ونشاطات المجتمع. 
• مدخل صحي: أي الإقناع عن طريق إظهار ما يحدث للنفس البشرية وكيفية إنقاذها. • مدخل اقتصادي: أي الإقناع عن طريق إظهار الأموال التي تستخدمها هذه الجماعات. • مدخل سياسى: أي الإقناع عن طريق عرض المشكلات السياسية، وكيفية حلها. جدول رقم (11) - مداخل الإقناع

\begin{tabular}{|c|c|c|}
\hline مداخل الإقناع & ك5 & $\%$ \\
\hline مدخل ديني & IT & \% \\
\hline مدخل ثقافي & 10 & $\% \vee \wedge . q$ \\
\hline ددخل اجتماعي & IV & $\% \wedge 9 . \varepsilon$ \\
\hline مدخل صحي & $\wedge$ & $\% \leq r .1$ \\
\hline ددخل اقتصادي & r & $\% 1 . .0$ \\
\hline مدخل سيأسى & $\wedge$ & $\% \leq r .1$ \\
\hline المجموع & 19 & $\% 1 \ldots$ \\
\hline
\end{tabular}

يوضح الجدول السابق مداخل الإقناع المستخدمة في الرسائل الإعلانية، حيث نجد أن أعلى نسبة كانت في المدخل الاجتماعي، بنسبة ؟.19\%، ويتضح ذلك من خلال إعلانات الحملة التيتم تصويرها

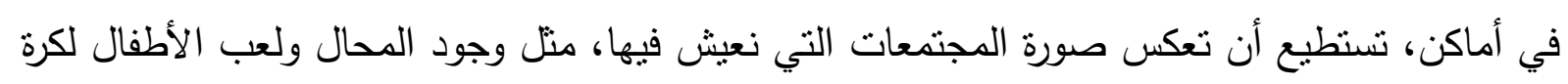

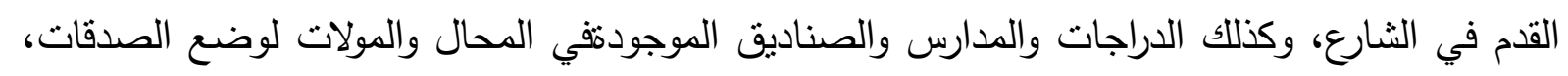

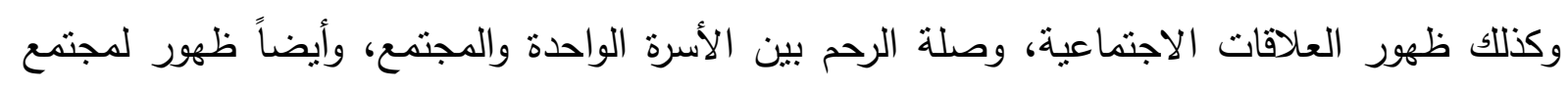

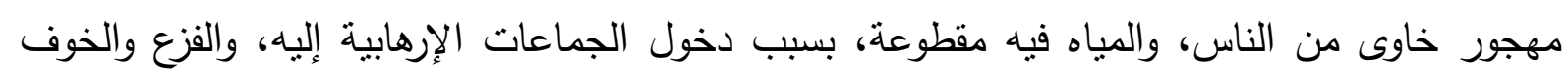

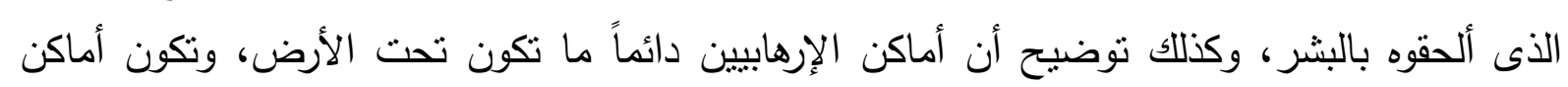
خفية.

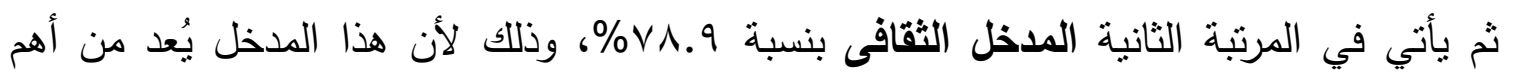

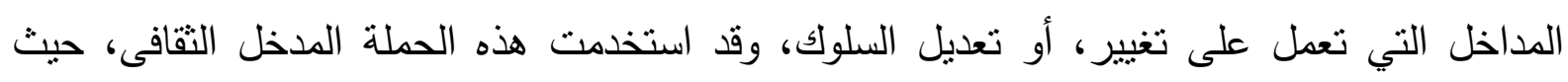
تهدف في الأساس إلى تغيير الثقافة، وتعديل سلوك الفرد تجاه المجتمع، وقد ظهر الأطفال وهم يقاتلون وتجاهل الابن لغضب أمه وخوفها عليه، وظهور سيارات يعتليها رجال ملثمون بمسكون بأسلحة يخيفون وتهن 
المارة حيث يجرون ويحاولون الهروب، ثم يقف شخص أمامهم فيقومون بتوجية السلاح تجاهه، وهو لا

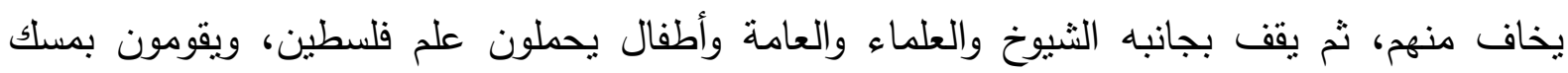

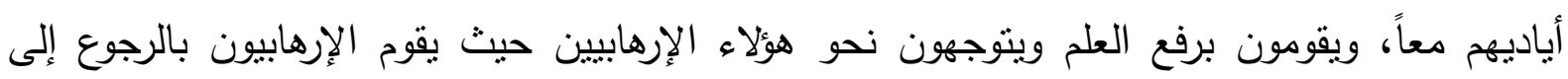
الخلف، وتظهر جملة المنطرف هو عدوك، فبذلك يحاول بث ثقافة الوحدة التي تواجه هذه الظاهرة. ونجد في المرتبة الثالثة المدخل الديني بنسبة ا.بr\%، وهدف هذا الدذخل هو إظهار تعاليم

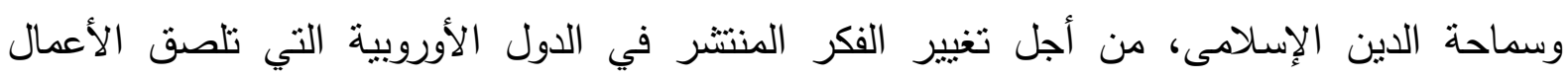

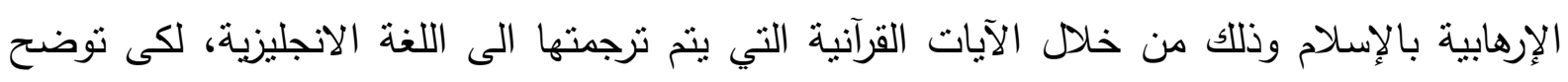

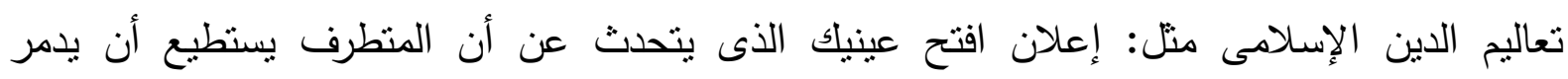

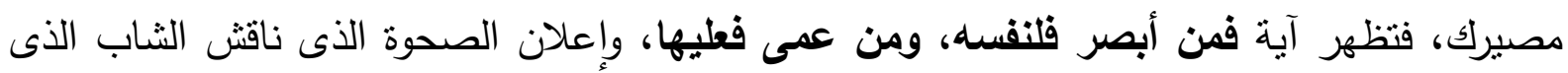

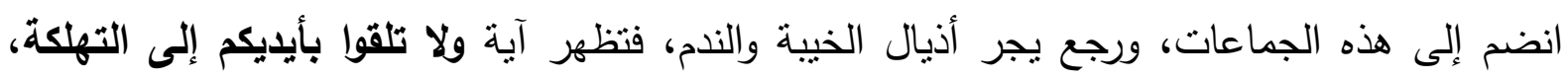

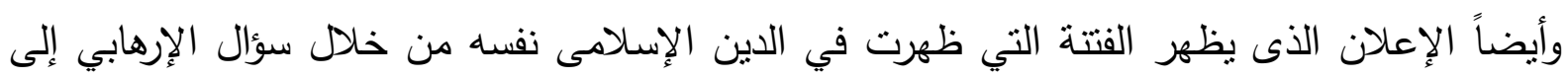

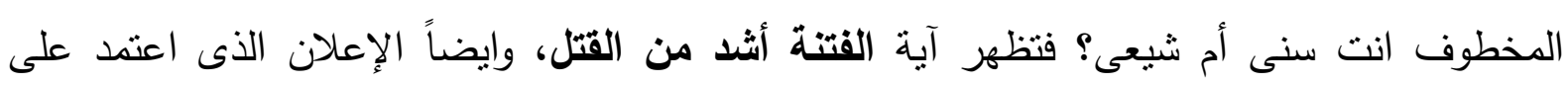

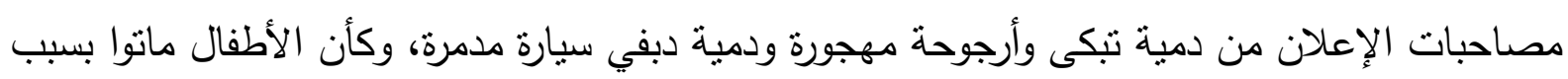

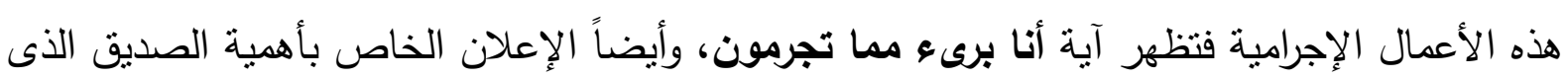

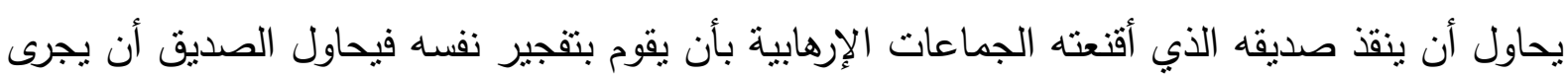

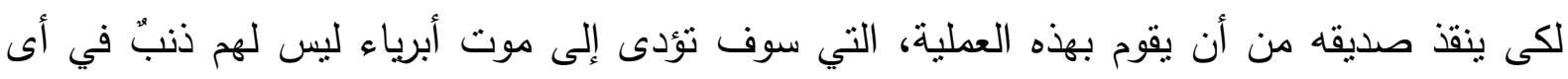

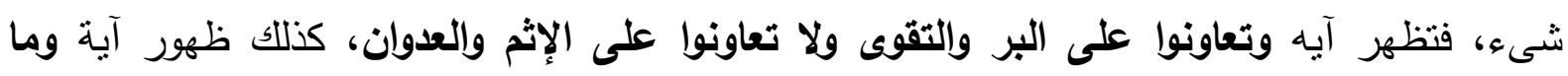

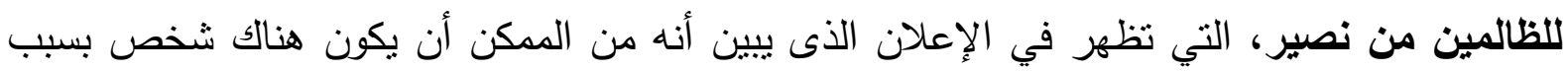

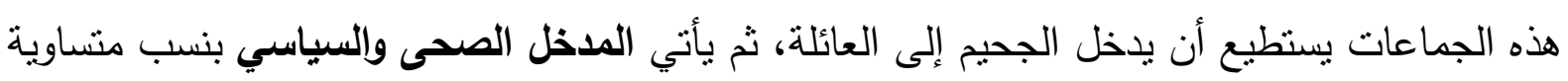

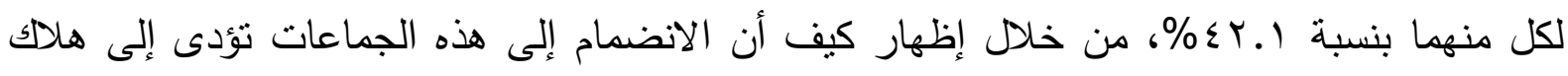

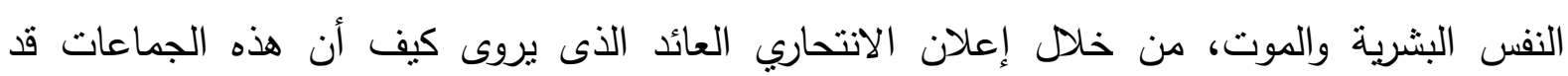

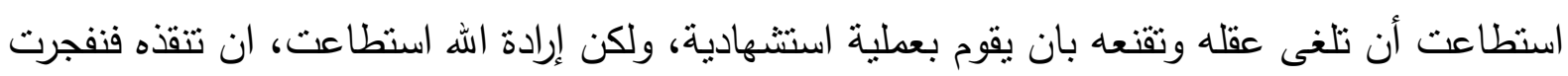
القبلة قبل ميعادها، ولكن الذى لحق به أنه أصبح لا بستطيع المشى لأن رجله اليسرى نم بنه بترها. r. أسلوب معالجة الهـف: هو الطريقة المستخدمة فى عرض الهدف من الحملة.

جدول رقم (Y I أسلوب معالجة الهدف

\begin{tabular}{|c|c|c|}
\hline أسلوب معالجة الهدف & ك & $\%$ \\
\hline عرض المشكلة & 1 & $\% 0 . r$ \\
\hline عرض الاثثين معاً & 11 & $\%$ q.$\vee V$ \\
\hline المجموع & 19 & $\% 1 \ldots$ \\
\hline
\end{tabular}




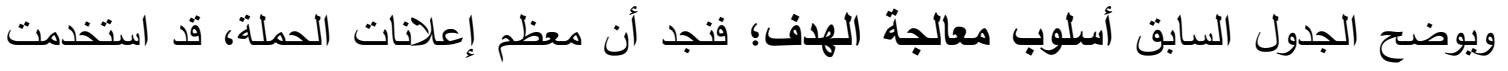

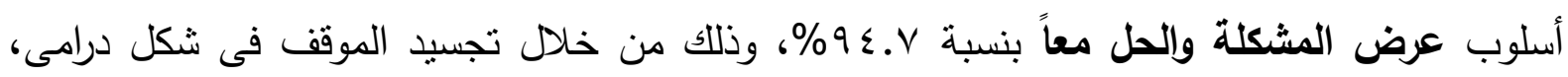

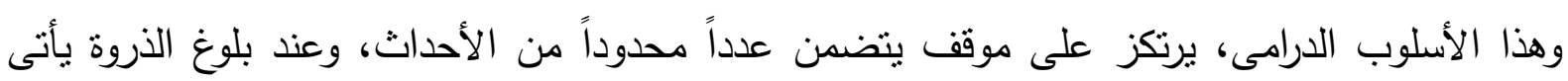

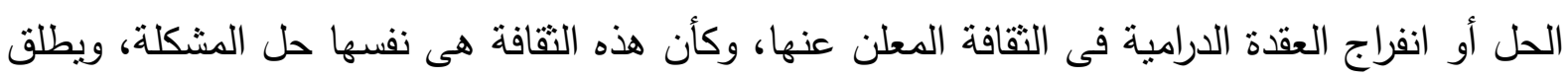

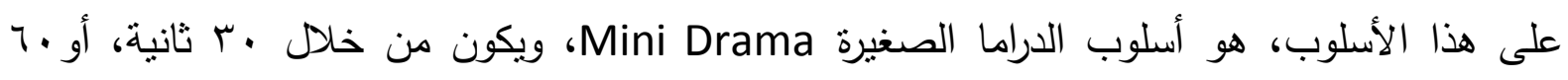

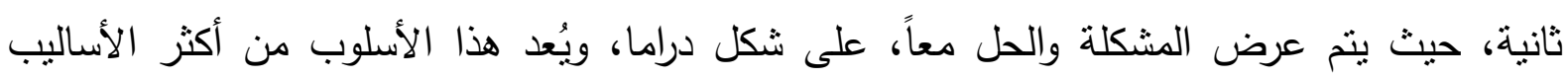

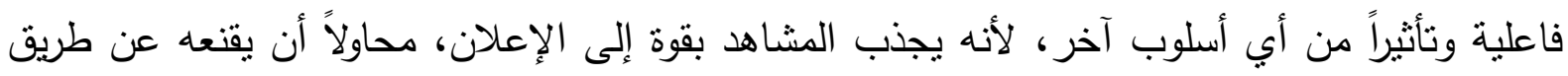

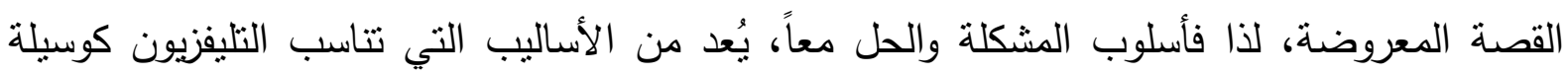

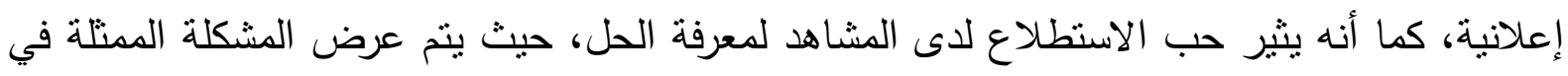

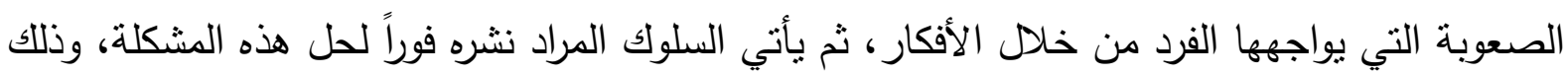

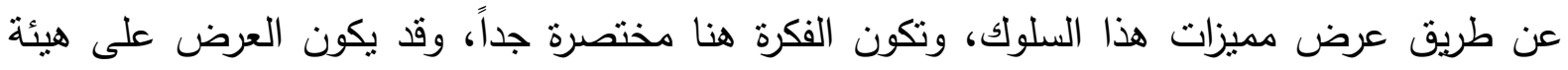
سؤال؛ ثم تأنى إجابته؛ ممثلة في تقديم الحل المباشر للمشكلة المطروحة من خلال الآيات القرآنية، والأحاديث، والجمل التي تظهر في نهاية الإعلان. لابعاً: الاستمالات المستخدمة في الرسالة: •استمالات عاطفية: أي الوسائل المعتدة على مخاطبة العاطفة. •استمالات الترغيب: أى الوسائل الجاذبة أو المؤثرة فى الجمهور • •استمالات عقلانية: أى الوسائل المعتدة على مخاطبة العقل وتقديم الحجج والبراهين. جدول رقم (r I الاستمالات المستخدمة

\begin{tabular}{|c|c|c|}
\hline الاستمالات & ك5 & $\%$ \\
\hline الاستمالات العاطفية & 11 & $\%$ q \\
\hline الاستمالات العقلانية & 11 & $\%$ q \\
\hline استمالات الترغيب & 19 & $\% 1 \ldots$ \\
\hline المجموع & 19 & $\% 1 \ldots$ \\
\hline
\end{tabular}

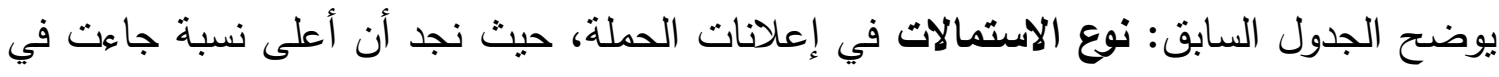

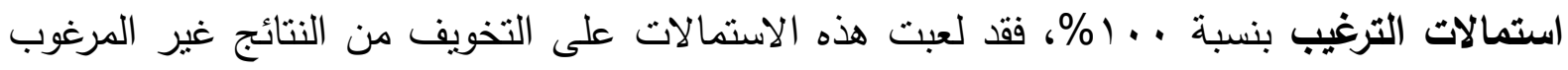

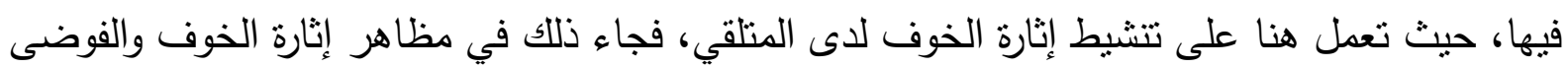




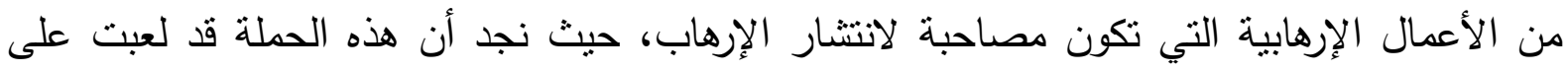
استثارة القيم الثخصية لدى الفرد، وظهر ذلك في مجموعة من الإعلانات فنجد إعلان اعرف عدوك لإنهابه

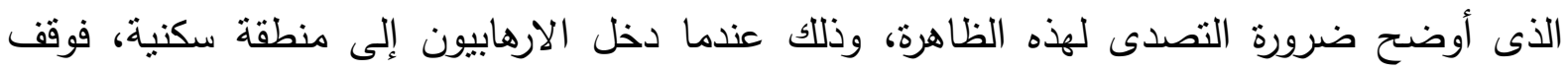

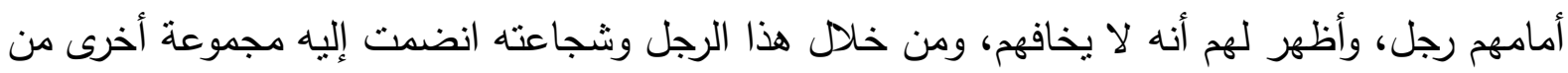

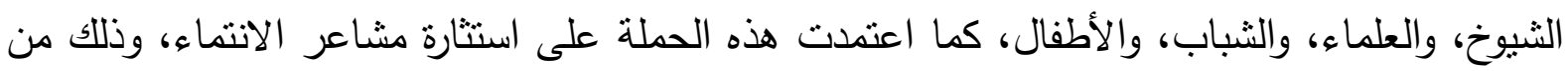
خلال ظهور طفل برفع علم فلسطين، ويحاول ألا يسقط من يديه ولكن الإرهابيقوم بإسقاط هذا الطفل

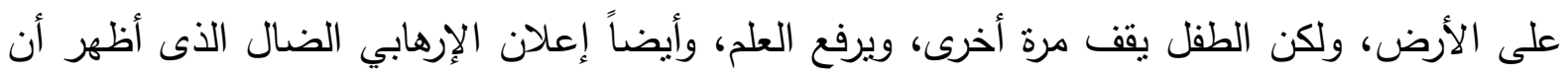

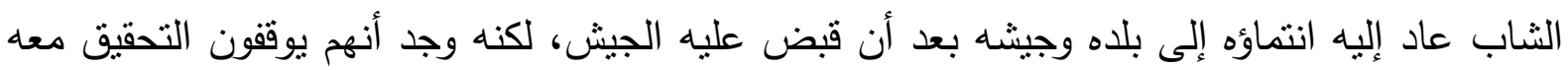

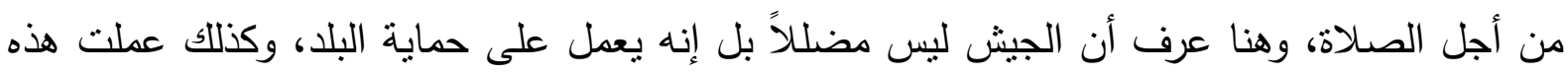

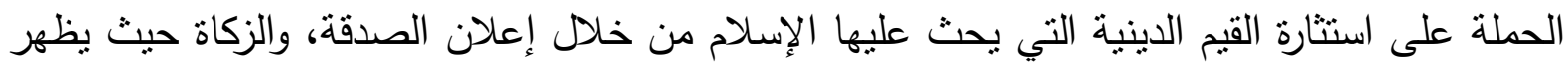

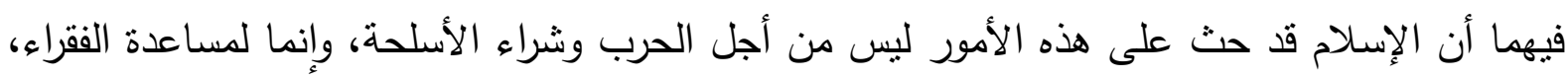

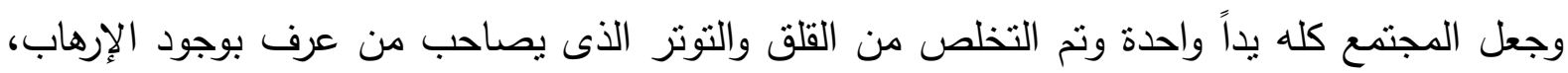
وذلك من خلا مشاهد الثوارع التي يسير فيها الناس في طمأنينه وسكينة، فعند ظهور الإرهابيين الذين

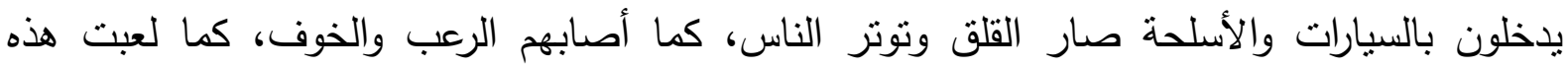

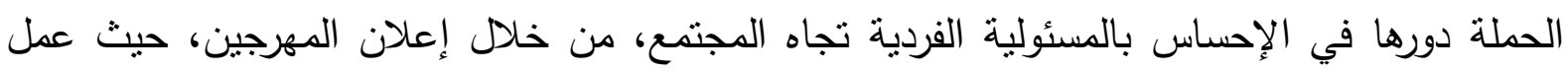
على عدم الاستسلام والخوف من الإرهابيين، من خلال ظهور المهرج الذى حاول أن يقوم بأعمال

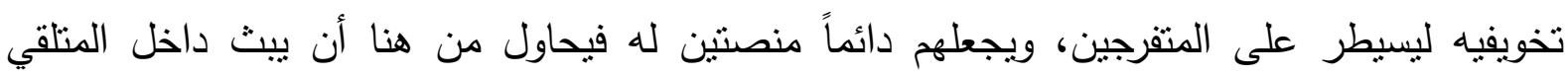

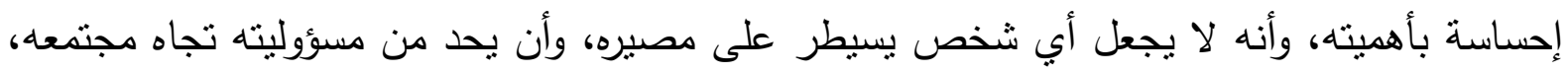

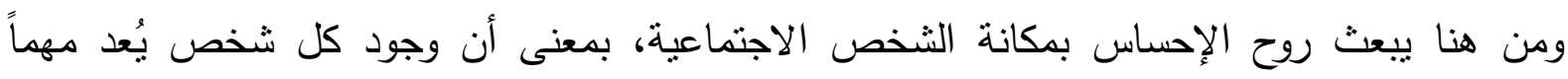

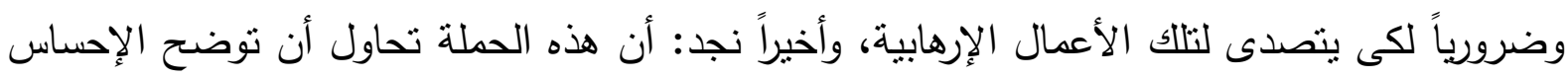

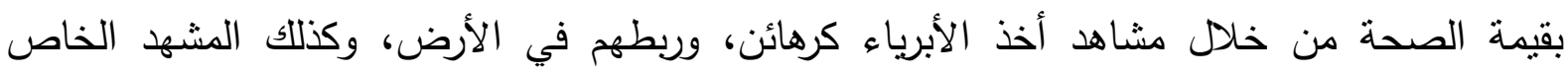

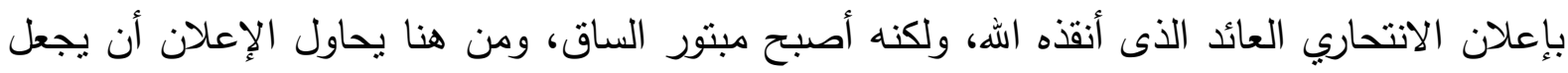
الهنلقي يربط بين هذه الجماعات وبين القضاء على حياتلك وعلى مستقبلك.

ثم نجد في المرتبة الثانية بنسب منساوية: الاستمالات العاطفية والاستمالات العقلانية بنسبة

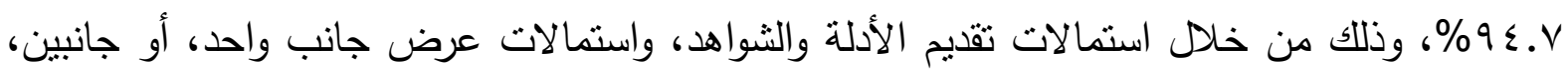

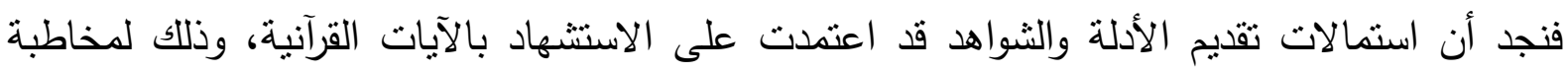

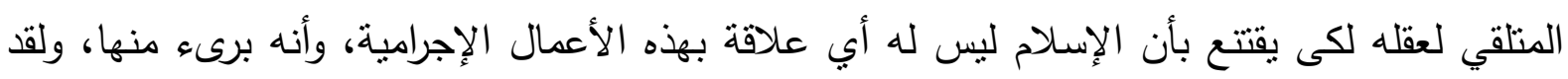

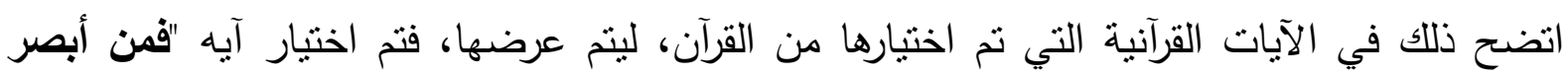

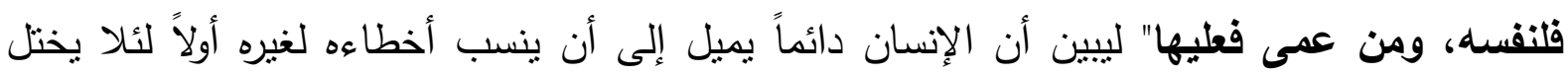

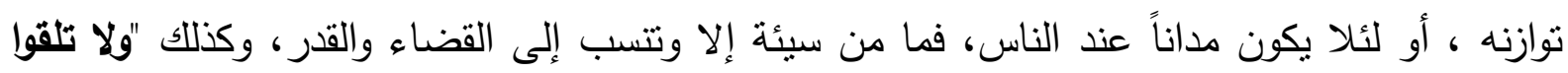


بأيديكم إلى التهاكة" والدقصود بها هنا هو: قتل النفس لأن اله قد حرم قتل النفس بأى طريق كان، وأن النفس بيد الله وحده.

وكذلك "الفتنة أثد من القتل" فقد كان المسلم يُفتنن فى دينه ليردوه إلى الكفر بعد إيمانه، فكان ذلك

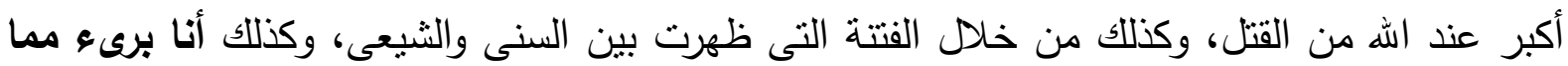
تجرمون بمعنى أن اله برىء من كل عمل بسيء إلى الدين الإسلامى، مثل قتل الأطفال والسيدات وكبار

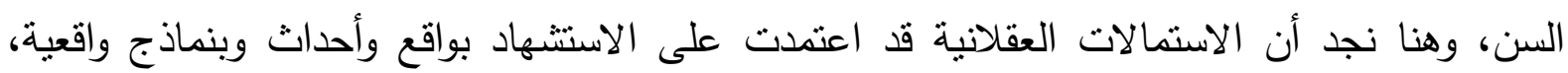
وذللك من خلال محاولة تجسيد الواقع الذى تحدث فيه هذه الأعمال، وكذلك الإعلانات الخاصة الإنة

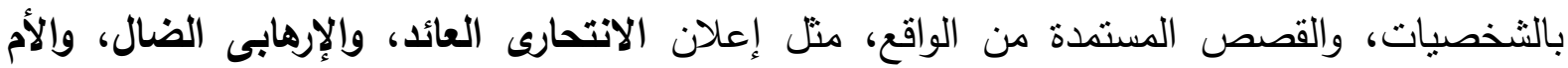

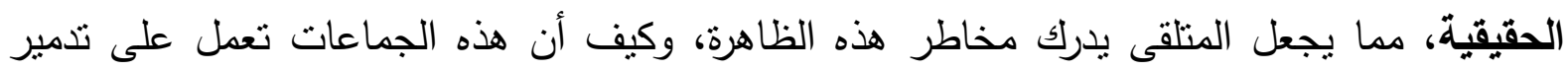
البلدان، ونتشر الفوضى، بالإضافة إلى المخاطر التى لحقت بمن انضم إلى هذه الجماعات، أما

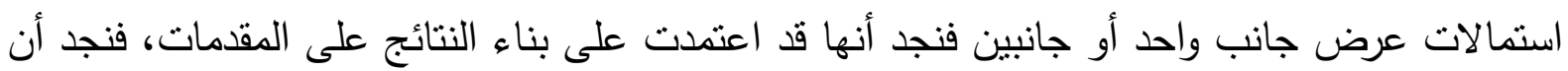
الإعلانات قد اعتمدت على عرض المشكلة فى البداية، وعند الوصول إلى الذروة فتم عرض النتيجة بناءً

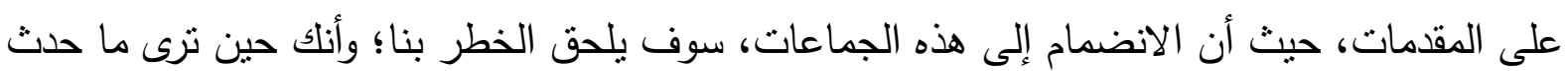
لغيرك، فسوف تختار أنت النهاية التى تريدها، مثل: إعلان الاتتحارى العائد عندما حكى الرجل قصته

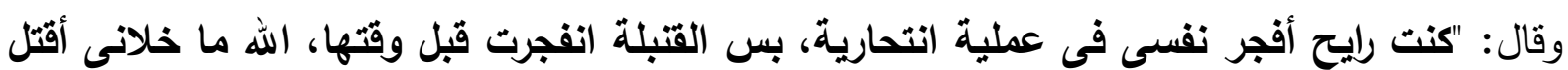
أطفالا وأبرياء، من يومها وأنا أكره نفسى، واستاهل اللى سار إنهار ويايا، إحنا ما كنا مجاهدين، إحنا مجرد أدوات للموت فى يد تنظيم القاعدة".

أما الاستمالات العاطفية هنا، فكانت تتجسد في استخدام الثتعارات والرموز، منل: ظهور الدمية

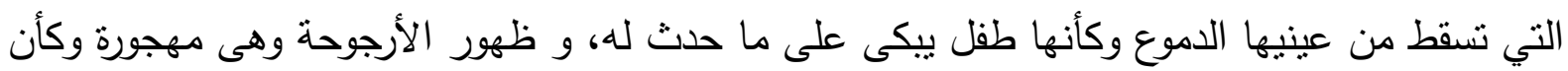
اللعب والفرح اختفيا مع ظهور الإرهاب، وكذللك التعبير الذى كان يظهر على على وجوه الثباب الذينتركوا هذه

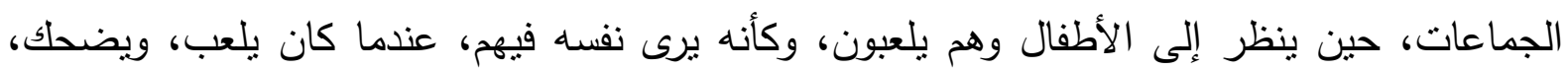

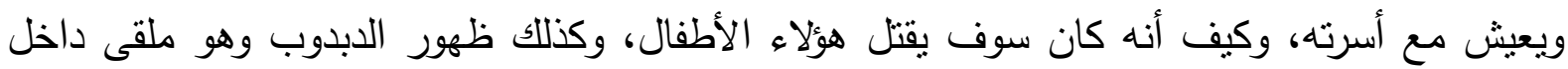

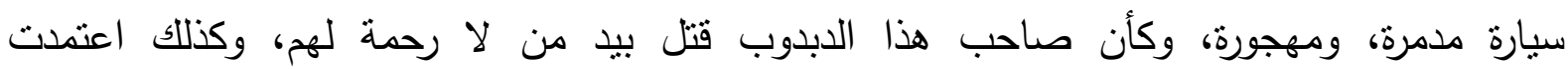

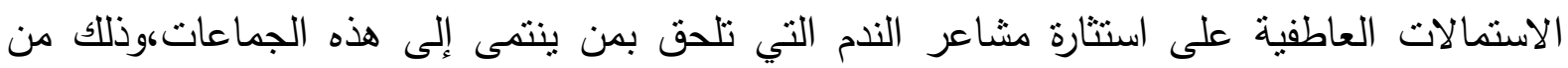

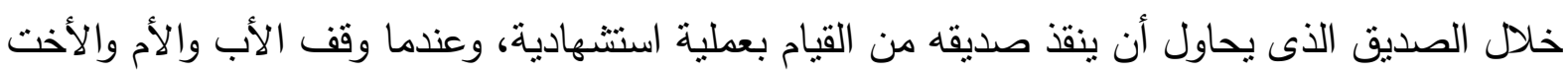

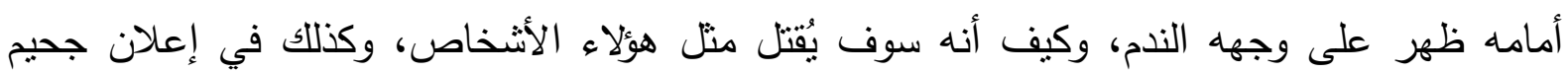

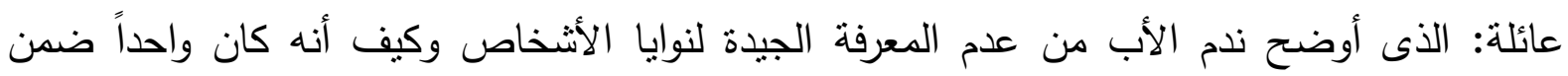
أسرته، ولكنه اكتشف بعد ذلك أنه من هذه الجماعات، وكذلكفي إعلان الإرهابي الضال الذى كان يحكى لإنى قصنه، بشعور من الندم ويقول: "لما مسكونى الثرطة، كنت مصدق إنهم أعداء الإسلام، مثل ما كانوا 
بالتنظيم يقنعونا، لكنهم عاملونى معاملة إسلامية صحيحة، ووقت الاستجواب، نادونى علثان أصلى معاهم، لحظتها عرفت كم كنا مضللين، اللهم اغفر لى، إنى كنت من الظالمين". وأيضاً مشاعر الندم التي صاحبت الثاب الذى انضم إلى هذه الجماعات، ولكنه وجد نفسه في طريق غير طريقه، فحاول الخروج، ولكنه عجز عن فتح أي باب كان أمامه حيث وجد مكتوباً عليه جزّوا

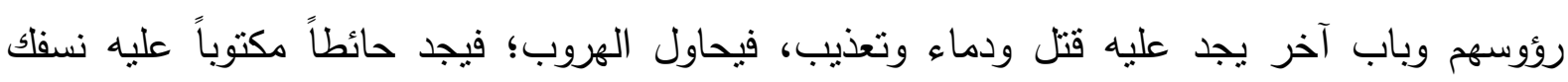

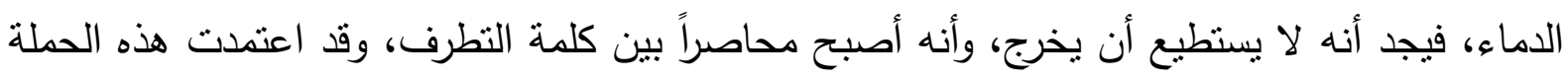

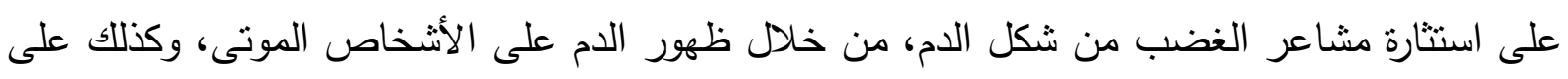

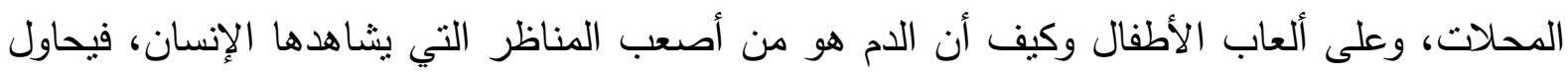

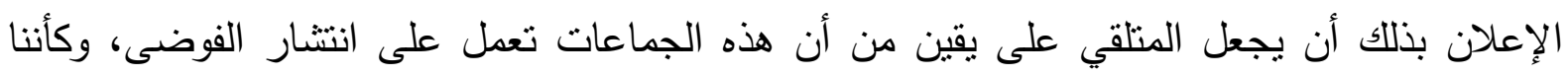

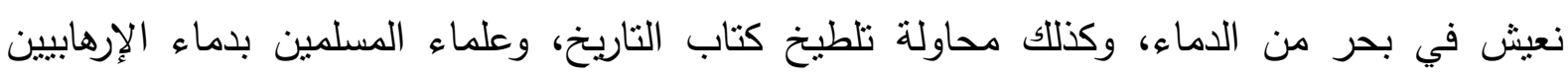
ومحاولتهم تثويه تاريخنا.

النتائج والاستخلاصات:

يتضح لنا أن هذه الحملة قد نوافرت بها مفاهيم التنسويق الاجتماعي، وهى: التحفيز، والوعى، التها،

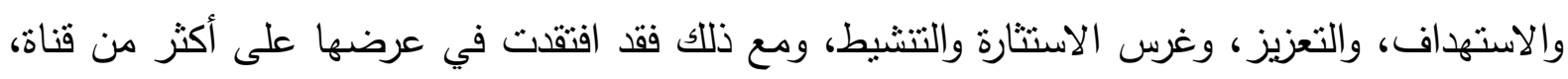

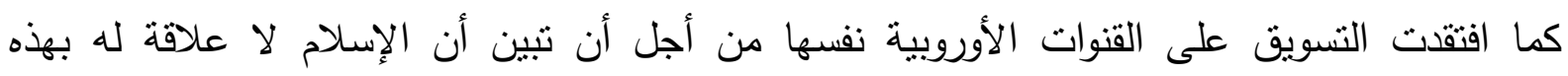
الأعمال الإرهابية.

ومن خلال تفسير وتحليل مضمون الحملات، وبالتوصل إلى أفضل الطرق التي تستطيع من خلالها

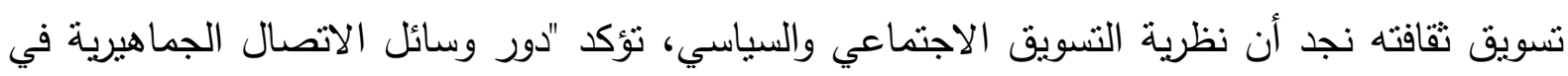

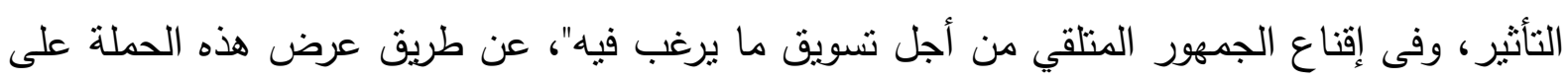

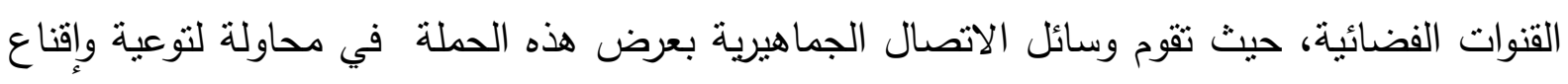

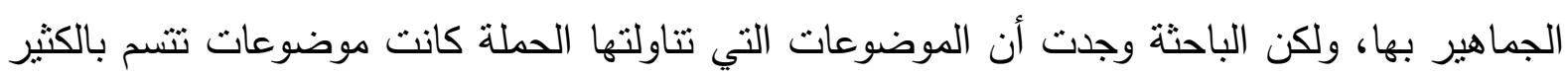

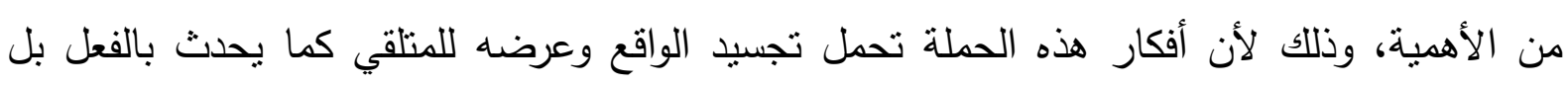
عملت على عدم عرض بشاعة وفظاعة الواقع الذى يحدث فيه الإرهاب.

ونجد أن هذه الحملة قد استعانت بالقوالب الدرامية أكثر، وذللك لأن قالب الدراما يجعل للمتلقي رغبة

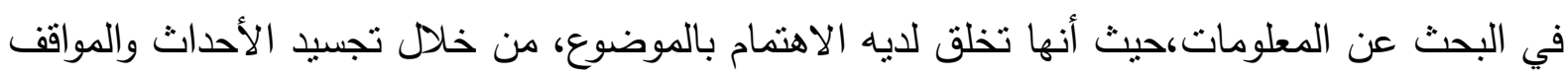
الدرامية.

وقد كثف البحث قله استخدام قالب الجرافيك، وذلك لتكلفته العالية، رغم سهولة توصيله للمعلومة، فمن أهم وظائف الرسوم المتحركة في الإعلان جذب انتباه الجمهور إلى الإعلان، بما يستطيع أن يعبر 
عن الفكرة المعينة سريعاً، وبشكل مبسط ومفهوم، مع إثارة اهتمام المشاهد بما يحتويه الإعلان من شخصيات، وحركات مشابهة للواقع، مما يعمل على إضفاء الواقعية، ويخلق درجة عالية من التذكر. كما نجد أن عملية المونتاج في إعلانات الحملة، من حيث نرتيب اللقطات ونتابعها وإيقاعها، وتوقيت المشه وسرعته، كل ذلك قد أثز في نجاح الإعلان لأن المونتاج يوفر التتويع بين المشاهد خشية الملل من خلا التقطيعات المختلفة، بين المشاهد، والزوايا المختلفة للحدث نفسه، حيث يعمل على تقديم العمل في قالب شيق، فيقدم بعض اللقطات على غيرها مع استخدامه بعض المؤثرات الصوتية، والبصرية، مما يساعد على خلق تأثيرات درامية، أومثيرة لا تتيسر في الواقع. أما بالنسبة لشعار الحملة وهو "الإرهاب أنا مسلم..أنا ضده" فتجد الباحثة: أنه كان من الأفضل إعادة صياغة هذا الشعار وذلك لأن هذا الشعار من الممكن أن تحدث إساءهفي فهمه، فمن الممكن جعله "الإرهاب أنا مسلم..أنا ضحيتهة.

ويبقى السؤال هنا: لماذا يلحق الغرب الأعمال الإرهابية بالدين الإسلامى في الوقت الذي يعلمون فيه جيداً أن من يقوم بهذه الأعمال هم الصهاينة ضد العرب المسلمين والمسيحيين داخل وخارج فلسطين وسوريا....... من قتل، واغتيال، وحرق، وتفجير ،وهم من يقومون بالتغلغل داخل مجتمعاتتا،لماذا لا نجد حملة تحمل اسم أنا يهودى.أنا ضد الإرهاب، وذللك لأن إعلامهم يعمل على تسويق ثقافتهم بشكل جيد حتى وإن كانت مخالفة لعقائدهم، بينما إعلامنا يسىء إلى ثقافتنا ولا يظهر سماحة ديننا. 


\section{المصادر والمراجيع}

أولاً: قائمة المراجع العربية:

1- الرسائل العلمبة:

1-مروة شميس:" فاعلية الحملات الإعلانية في مواجهة العنف ضد المرأة "، رسالة دكتوراه، القاهرة كلية الآداب، قسم

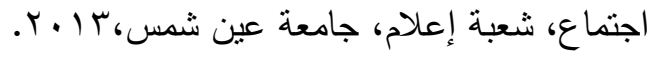

Y-سلوى سليمان عبد الحميد، التسويق السياسي للأحزاب والجماعات السياسية المصرية-دراسة نطبيقية على الانتخابات

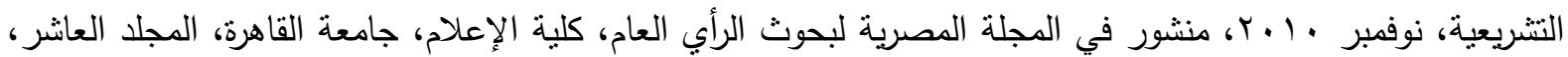

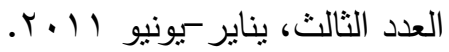

rسلوى العوادلى:" دور حملات التسويق الاجتماعي في دعم مفهوم المواطنة ومناهضة الاستبعاد الاجتماعي"، منشور

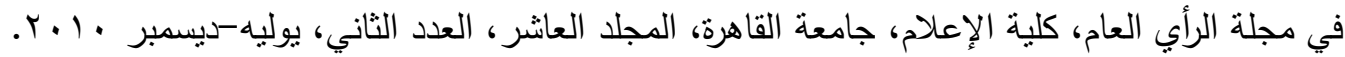
4- داليا السواح:" دور إعلان الخدمة العامة في المشاركة الاجتماعية للجمهور"، رسالة ماجستير، القاهرة، كلية الآداب،

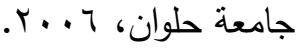
5- وسام محمد أحمد نصر: "دور حملات التوعية في الراديو والتلبفزيون في التثقيف الصحي للمرأة المصرية"، رسالة

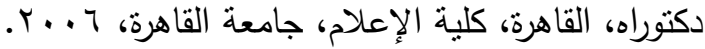
6- علاء عبد المجيد يوسف الثنامي: "دور الخطاب الدينيفي وسائل الاتصال في تتكيل اتجاهات الثباب المصري نحو القضايا السياسية"، رسالة دكتوراه، القاهرة، كلية الإعلام، جامعة القاهرة، 7 ... T. 7- سهير عثمان عبد الحليم: علاقة تعرض الثباب للصحافة المطبوعة والإككترونية باتجاهاتهم نحو ظاهرة الإرهاب، رسالة دكتوراه، القاهرة، كلية الإعلام، جامعة القاهرة، 7 . . T.

8- أحمد فاروق رضوان: مدى الاعتماد على وسائل الإعلام العربية والدولية كمصدر للحصول على المعلومات، رسالة

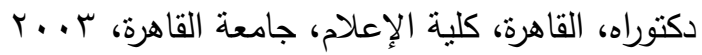
9- جيهان يسرى: اتجاهات الإعلاميين نحو تغطية الإعلام المصري لأحداث الإرهاب، المؤتمر العلمي الثامن، كلية الإعلام، جامعة القاهرة، مايو r. r...

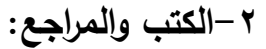

ا-نبيل عبد الفتاح، الرؤى الملتبسة: الإعلام والإرهاب، ـ ا ـب، المركز العربي للبحوث والدراسات. Y-سلوى العادلي، النسويق الاجتماعي، الطبعة الأولى، القاهرة. دار النهضة العربية، II ـr. ז-محمد فريد الصحن، مصطفى محمود، بحوث التسويق، الطبعة الثانية، الإسكندرية. الدار الجامعية الإسكندرية، .1999

ع -فؤاده عبد المنعم البكري، التسويق الاجتماعي وتخطيط الحملات الإعلامية، الطبعة الثانبة، القاهرة. عالم الكتب، $.4 \cdot 11$

ه-عبد العزيز سرحان، تعريف الإرهاب الدولي وتحديد مضمونه، المجلة المصرية للقانون الدولي، مج9 ب، بV9 ا. 


$$
\begin{aligned}
& \text { 7-عصام صادق رمضان، الأبعاد القانونية للإرهاب الدولي، مجلة السياسة الدولية، العدد 10، } 1911 \text {. }
\end{aligned}
$$

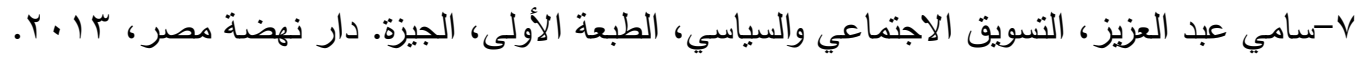

$$
\begin{aligned}
& \text { ^-كريمان فريد، المسئولية الاجتماعية والتسويق الاجتماعي، الطبعة الأولى، القاهرة. دار النهضة العربية، ج . . } \\
& \text { ثانياً: قائمة المراجع الأجنبية: }
\end{aligned}
$$

1- Stred, M. and Gordon, R. and Angus, K., (, 2007), "A systematic review of social marketingeffectivness", Health Education, vol. 107, No. 2,

2- Tondo,J.and Suyper, 2002," "The influence of organizational characteristics \& campaign design elements on communications"

3- Bhattacharya,C. and Kimberly,d., 2002,"Usversus them the role of organizationale identification \& didentification in social marketing initiatives"

4- Seth C. Lewis \& Stephen D. Reese. "what is the war on terror? Framing through the eyes of journalists" journalism \& mass communication quarterly, vol.86. no.1,2009.pp.85-102

5- Pew internet \& American life project "Ayear later: the internet \& September 11" Available at: http://www.pewinternet.org"

ثالثاً: مراجع الانترنت

www.arabobservatory.com 